Natural Hazards and Earth System Sciences, 5, 477-494, 2005

SRef-ID: 1684-9981/nhess/2005-5-477

European Geosciences Union

(C) 2005 Author(s). This work is licensed

under a Creative Commons License.

\title{
Residential building and occupant vulnerability to tephra fall
}

\author{
R. J. S. Spence ${ }^{1}$, I. Kelman ${ }^{1}$, P. J. Baxter ${ }^{2}$, G. Zuccaro ${ }^{3}$, and S. Petrazzuoli ${ }^{3}$ \\ ${ }^{1}$ Department of Architecture, University of Cambridge, UK \\ ${ }^{2}$ Institute of Public Health, University of Cambridge, UK \\ ${ }^{3}$ Centro Interdipartmentale LUPT, University of Naples, Italy
}

Received: 8 December 2004 - Revised: 5 April 2005 - Accepted: 25 April 2005 - Published: 18 July 2005

\begin{abstract}
Plinian and subplinian volcanic eruptions can be accompanied by tephra falls which may last hours or days, posing threats to people, buildings and economic activity. Numerous historical examples exist of tephra damage and tephra casualties. The mechanisms and consequences of roof collapse from static tephra load are an important area of tephra damage requiring more research.

This paper contributes to this work by estimating the structural vulnerability of buildings to tephra load based on both analytical studies and observed damage. New studies are presented of roof strengths in the area around Mt. Vesuvius in southern Italy and of field surveys undertaken in other European volcanic locations to assess building vulnerability to tephra fall.

The results are a proposed set of new European tephra fall roof vulnerability curves in areas potentially threatened by explosive volcanic eruptions along with comments on the human casualty implications of roof collapse under tephra loading. Some mitigation recommendations are provided.
\end{abstract}

\section{Introduction}

Plinian and subplinian volcanic eruptions can be accompanied by tephra falls which may last hours or days. Such a tephra fall can cover an extensive area with a tephra thickness sufficient to cause serious damage to buildings and massive disruption to human activity, as shown by the past events summarised in the Appendix. Examples of the potential destructive power of tephra in possible future events are outlined by Barberi et al. (1990) for the area around Mt. Vesuvius, Italy; Bonadonna and Sparks (2002) for Montserrat; and Connor et al. (2001) for León, Nicaragua.

The composition, depth, density and particle size distribution of the tephra deposit can vary widely from volcano to volcano and from place to place affected by a single eruption.

Correspondence to: R. J. S. Spence

(rspence@ carltd.com)
Large variations of these tephra parameters are even possible within the deposit at one location from a single eruption. The pattern of initial deposition depends on the nature of the eruption, the dynamics of the different particles, and the weather, especially wind and precipitation, at the time of the eruption.

In line with standard volcanological definitions, tephra is taken here to include ash, lapilli, blocks, and bombs, i.e. any accumulation of airborne pyroclasts. Tephra falls can be harmful to human health and livelihoods, buildings and other infrastructure, economic activities, and ecosystems. Close to the eruption's source, tephra falls can include blocks and bombs of sufficient mass to cause severe injury or death to people struck by them as well as to puncture sheet roofs and windows with the potential consequence of fire. For some distance from the source, up to tens of kilometres, tephra falls can accumulate to sufficient depth to cause roof collapse, causing further death and injury. Tephra can also be disruptive to agriculture, transport, communications, and industry. These sectors can be impacted even in regions distal to the main volcanic plume.

Because of tephra's widespread effects, civil protection authorities often have a difficult task in identifying areas which need to be evacuated when volcanic activity, which often includes tephra, threatens or occurs. Insufficient evacuation could put inhabitants at risk whereas over-extensive evacuation could be socially and economically damaging. The 1976 evacuation of 73600 people from Guadeloupe for three and a half months (e.g. Sigvaldason, 1978; Tazieff, 1977) and the Montserrat evacuation debate and risk zonation since 1995 (e.g. Clay, 1999; Pattullo, 2000) are examples of these challenges in practice. Providing buildings and facilities with the capability to resist the likely effects of an eruption, including tephra, could reduce the urgency of evacuation as well as easing post-event reoccupation and recovery.

This paper addresses tephra vulnerability in five parts. After this introduction, a review of the tephra fall hazard to buildings is presented, largely based on observations from historical events. Then, new research in the form of a 
Table 1. Damage distribution of the Pinatubo sample.

\begin{tabular}{llccc}
\hline Damage level & Description & $\begin{array}{c}\text { Number of } \\
\text { buildings }\end{array}$ & $\begin{array}{c}\text { Percentage in } \\
\text { damage level }\end{array}$ & $\begin{array}{c}\text { Percentage with } \\
\text { damage at or } \\
\text { exceeding level }\end{array}$ \\
\hline D0 & No damage & 15 & 29 & 100 \\
D1 & Light roof damage & 3 & 6 & 71 \\
D2 & Moderate roof damage & 8 & 16 & 65 \\
D3 & $\begin{array}{l}\text { Severe roof damage and some damage } \\
\text { to vertical structure }\end{array}$ & 8 & 16 & 49 \\
D4 & $\begin{array}{l}\text { Partial roof collapse and moderate dam- } \\
\text { age to rest of building }\end{array}$ & 9 & 18 & 33 \\
D5 & $\begin{array}{l}\text { Complete roof collapse and severe dam- } \\
\text { age to the rest of the building }\end{array}$ & 8 & 16 & 16 \\
& & & & \multirow{2}{*}{} \\
\hline
\end{tabular}

vulnerability assessment of buildings to tephra is presented. Recent studies of existing European residential buildings are used to propose a set of vulnerability relationships suitable for these building types. This research forms the basis for some recommendations for mitigation policy and practice in Sect. 4. Finally, general conclusions and further research directions are discussed.

\section{Case studies of tephra fall and buildings}

\subsection{Overview}

The Appendix summarises 27 eruptions for which significant tephra fall effects have been recorded. In many cases, roofs collapsed killing occupants. Tephra fall has historically not been the most lethal volcanic hazard - since AD 1 , it has been identified as the cause of death in an estimated $2 \%$ of recorded volcano fatalities (Simkin et al., 2001) - but it has been the most frequently occurring cause of death, being cited as a cause of death in $21 \%$ of volcanic eruptions (Simkin et al., 2001). Tephra's economic effects have also been significant in many of the events listed in the Appendix.

The instances in the Appendix point to several aspects of tephra fall which need to be considered if useful vulnerability estimates are to be made. These aspects are discussed in Sects. 2.4-2.8, but first the only two published tephra damage surveys of significant numbers of buildings are summarised: Spence et al. (1996) for the Pinatubo eruption of 1991 (Sect. 2.2) and Blong (2003) for the Rabaul eruption of 1994 (Sect. 2.3).

\subsection{Pinatubo, 1991}

Mt. Pinatubo's eruption on 15 June 1991 caused a vast tephra fall with several settlements, including Olangapo and Castillejos, experiencing a tephra fall depth of more than $15 \mathrm{~cm}$. The pre-eruption evacuation of tens of thousands of people limited loss of life. In the immediate aftermath of the eruption, more than 300 people died and several hundred were injured (estimates vary widely), mostly from tephrainduced roof collapse (Newhall and Punongbayan, 1996).

A building damage survey was carried out on 29 June 1991, two weeks after the main tephra fall event, by the Field Epidemiology Training Program Team of the Department of Health, Manila, the Philippines. This survey studied the impact of the tephra fall on two towns: Olangapo, where the tephra depth was about $15 \mathrm{~cm}$, and Castellejos, where the tephra depth was about $20 \mathrm{~cm}$. The most detailed survey was completed in Castellejos, where a building-by-building photographic record was carried out for all the buildings in a particular sector, whether damaged or not. There were 51 buildings in this survey, a small but representative sample of the buildings in this town with 50000 pre-eruption inhabitants. This photographic record was then sent for analysis to building damage specialists at Cambridge University, UK (Spence et al., 1996).

Analysis showed the distribution of the buildings in the survey by construction type, roof support, roof pitch, and building usage. The most common construction types were reinforced concrete frame $(41 \%)$ and timber frame $(33 \%)$. $65 \%$ of the buildings in the sample were residential. A damage scale was derived from the European Macroseismic Scale for earthquake damage (Grünthal, 1998) and the damage distribution of the whole sample was tabulated (Table 1).

Principal outcomes from the damage survey were:

1. Tephra could accumulate up to $15 \mathrm{~cm}$ on the roofs in this area without damage.

2. Analysis of sub-samples of the data was done to investigate the relationship of damage level to construction, concluding that:

- Damage was worse if the roof had a long span (>5 m).

- Damage was worse for timber frame construction.

- Damage was worse if the roof had wide overhangs.

- Damage was worse for non-residential than for residential buildings.

- The effect of roof pitch was ambiguous. 
Table 2. Proportions of Rabaul sample suffering roof failure under given tephra load (derived from Blong, 2003).

\begin{tabular}{cccccccc}
\hline $\begin{array}{c}\text { Tephra load } \\
\text { range }(\mathrm{kPa})\end{array}$ & $\begin{array}{c}\text { Mean value of } \\
\text { tephra load }(\mathrm{kPa})\end{array}$ & $\begin{array}{c}\text { Number of timber } \\
\text { frame buildings }\end{array}$ & $\begin{array}{c}\text { Total } \\
\text { in sample }\end{array}$ & $\begin{array}{c}\% \text { timber } \\
\text { frame }\end{array}$ & $\begin{array}{c}\text { Number of } \\
\text { residential } \\
\text { buildings }\end{array}$ & $\begin{array}{c}\text { Total } \\
\text { in sample }\end{array}$ & $\begin{array}{c}\% \\
\text { residential }\end{array}$ \\
\hline $0-2.5$ & 1.25 & 0 & 21 & 0 & 0 & 15 & 0 \\
$2.5-5$ & 3.75 & 9 & 19 & 47 & 6 & 17 & 35 \\
$5-7.5$ & 6.25 & 6 & 8 & 75 & 4 & 7 & 57 \\
$7.5-10$ & 8.75 & 21 & 21 & 100 & 6 & 6 & 100 \\
$10-15$ & 12.5 & 17 & 17 & 100 & 20 & 20 & 100 \\
\hline
\end{tabular}

3. Measuring ash density is essential to know the load on the roof. Ash densities at Clark Air Base, about $12 \mathrm{~km}$ from Mt Pinatubo, were 1200 to $1600 \mathrm{~kg} / \mathrm{m}^{3}$ for dry ash and 1500 to $2000 \mathrm{~kg} / \mathrm{m}^{3}$ for wet ash.

4. Roof design for tephra loads of $2.0 \mathrm{kPa}$ would have eliminated much of the damage.

5. Advice to sweep roofs during tephra falls, such as that given during the 1973 eruption beside Heimaey in Iceland, may be difficult or dangerous in many circumstances, leading to additional casualties.

6. Earthquakes occurred, but did not contribute significantly to observed damage.

\subsection{Rabaul, 1994}

The 19 September 1994 eruption of the two volcanoes Taravur and Vulcan, $4 \mathrm{~km}$ and $6 \mathrm{~km}$ respectively from the town of Rabaul in Papua New Guinea, provided an opportunity for a building damage survey. Details of this eruption are given by Blong (1994), Blong (2003), and Blong and McKee (1995). An ad hoc evacuation of the entire 15000 population of Rabaul resulted in limited loss of life. Four people were killed, three of which were tephra-related, but building damage was extensive.

Airfall tephra of a depth ranging from $13 \mathrm{~cm}$ to over $90 \mathrm{~cm}$ thickness covered the whole town (Blong, 2003). The density of wet tephra from Vulcan was 800 to $1000 \mathrm{~kg} / \mathrm{m}^{3}$ while the density from Tavurvur was 1700 to $1900 \mathrm{~kg} / \mathrm{m}^{3}$. Most locations received tephra from both sources, although Rabaul received most of its tephra from Tavurvur. Based on these on density measurements, buildings received an estimated load ranging from under $2 \mathrm{kPa}$ to over $15 \mathrm{kPa}$.

A study of 173 buildings was carried out by Blong (1994, 2003) and insurance loss assessors between 1 and 4 weeks after the eruption. The buildings were not a completely representative sample of the buildings in Rabaul. Instead, they were mostly those covered by insurance and therefore tended to represent the better buildings. The buildings were divided into 11 construction categories according to the materials, structural framing system, and number of storeys. A subdivision by use into residential and non-residential (commercial and industrial) was made.

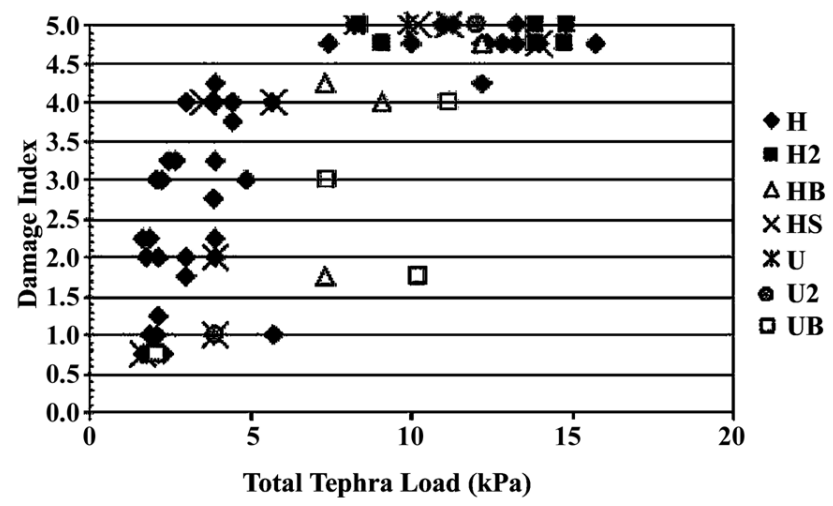

Fig. 1. Total tephra load versus damage index for the sample of residential buildings. In the key, $H$ is house, $U$ is apartment or unit, $B$ is concrete block construction, $H S$ is highset house, and numerals indicate the number of storeys if more than one (from Blong, 2003 reprinted with kind permission from the author and publisher).

The largest category was single-storey timber-framed buildings with a metal sheet roof, representing 88 of the 173 buildings and encompassing both residential and commercial buildings. For each building, the ash depth, construction type and details of damage were recorded. To record the damage, a new damage scale was proposed, derived from that proposed for the Pinatubo survey (see Table 1). In assigning a damage index to each building, intermediate values were used if there was evidence to support that (Fig. 1).

The survey of residential buildings showed a relatively consistent trend relating damage and tephra load, without significant variation among the different construction types (Fig. 1). Broadly, tephra load greater than $2 \mathrm{kPa}$ was needed for damage, and tephra load greater than $7.5 \mathrm{kPa}$ was likely to cause collapse. Blong's (2003) data were further analysed here to estimate the proportion of buildings suffering roof failure or collapse (damage index >3.5) among two classes of buildings: all residential, and all timber framed buildings with sheet roofs (Table 2).

Some other conclusions from this survey were:

- Both purlin and rafter failures occurred.

- A design load of 2.5-3.0 kPa would have been needed to prevent most of the damage. 


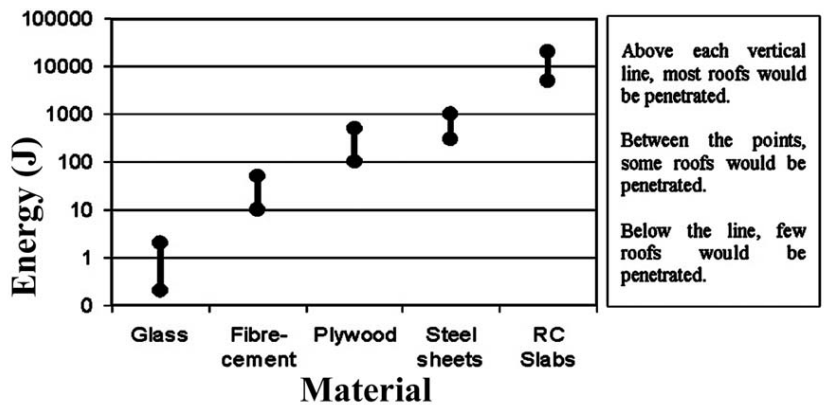

Fig. 2. The relationship between impact energy and the damage caused to a range of building materials, based on Blong (1984) and Pomonis et al. (1999).

- Insufficient data were available to study effect of roof pitch.

- Longer span roofs appear to be more vulnerable.

- No evidence of ash drifting was seen.

- Corrosion effects and protection from mudfill should be considered in future building codes.

\subsection{Tephra depth and static roof load}

Isopach maps are often produced after volcanic eruptions, showing the approximate distribution of thickness of the airfall tephra layer through contours. However, as indicated in discussing the two surveys, the important quantity to determine for the purpose of estimating effects on roofs is the maximum load, or load per unit area, which depends on ash density and ash thickness:

Tephra load $=\rho g h$

$g=$ Gravitational acceleration $\left(9.80665 \mathrm{~m} / \mathrm{s}^{2}\right), \quad h=$ Tephra thickness or depth $(\mathrm{m})$, and $\rho=$ Tephra density $\left(\mathrm{kg} / \mathrm{m}^{3}\right)$.

Density depends on the composition of the tephra (particularly the proportions of solid and vesiculated particles), on the degree of compaction, and the tephra's wetness either on deposition or from subsequent rainfall. Tephra density can therefore change with both time and weather. Dry tephra densities can range from approximately $400 \mathrm{~kg} / \mathrm{m}^{3}$ (e.g. Blong, 1981 suggesting a generic value) to over $1600 \mathrm{~kg} / \mathrm{m}^{3}$ (e.g. Blong, 1996 suggesting a generic value) depending on compaction. Wet tephra densities are reported as ranging from approximately $800 \mathrm{~kg} / \mathrm{m}^{3}$ (e.g. tephra from Vulcan, Papua New Guinea in 1994, Blong, 2003) to $2000 \mathrm{~kg} / \mathrm{m}^{3}$ (e.g. the Editor's note in Spence et al. (1996) discussing tephra from Mt. Pinatubo at Clark Air Base in 1991). Given this range, any relationship between roof strength and tephra thickness would have a large uncertainty. Thus, in this study, the tephra fall hazard will be defined by tephra load $(\mathrm{kPa})$.

Even if the tephra load on the adjacent ground is known or can be derived from an isopach map, the maximum load experienced by a roof may be different for several reasons:
- Tephra may slide off a sloping roof.

- Tephra on a roof may either be wetter or drier than that on the ground depending on drainage conditions.

- Occupants could clear roofs as the fall occurs or between successive falls.

- Tephra may drift, accumulating on some parts of roofs more than others.

- Wind or driving rain could blow tephra off roofs.

- A layer of ash, or possibly lapilli, can protect a building from blocks and bombs by cushioning the impact.

Structural failure through overload is not the only hazard. Pumice or lithic blocks of variable sizes can be a major and early component of the tephra fallout, and can penetrate or smash weak roofs with their impact energy. Ballistic ejecta with much shorter ranges can penetrate roofs and windows with the additional hazard of triggering fires inside buildings, as they shatter on final impact and spread hot debris over flammable furnishings.

\subsection{Tephra particle size}

Particle size distribution of the tephra on a roof affects the tephra density, thus also affecting the correlation between tephra depth and roof load. Particle size distribution and particle type also dictate the water absorption potential of tephra on a roof. Therefore, some discussion related to tephra composition on a roof would assist in understanding building vulnerability to tephra.

The tephra particle size distribution from an eruption at a location depends on factors related to the specific nature of the volcanic eruption, mainly eruption style and column height. Location within the plume also affects the tephra characteristics experienced, because they vary not only with distance from the volcano's vent along the plume but also along the axis perpendicular to the plume. Finally, weather is a major factor, because wind distributes tephra while rain washes fine particles out of the air closer the volcano.

Pyle (1989) provides an extensive analytical framework backed up by empirical evidence for tephra particle size and distribution around a volcano, indicating the complexity of the problem. He also provides a useful summary of equations to use for determining maximum clast size based mainly on type of volcanic eruption. The important outcome for this study is that a building or person within tens of kilometres of an erupting vent could experience a wide variety of particle size distributions and maximum clast sizes; however, if the eruption type is known, then it becomes possible to provide a better prediction of the nature of the tephra likely to be experienced at a certain distance from the vent for different wind scenarios.

This general statement is useful for considering the possibility of buildings being impacted by clasts which act as missiles; i.e. tephra-induced building damage due to the impact energy rather than due to the static roof load. Cases of 
blocks and bombs penetrating roofs are reported in the literature. Blong (1984) and Pomonis et al. (1999) consolidate and summarise this information (see Fig. 2).

Blocks and bombs also cause casualties, mainly to people caught without shelter, through skull or vertebrate fracture, other broken bones, and amputations. One example was the 14 January 1993 eruption of Galeras, Colombia which killed nine people and injured several more for which "the main cause of death and serious injury was the fusillade of flying and falling hot rocks which continued for about 15 min after the onset of the eruption with the size of the missiles ranging from boulder ( $>1 \mathrm{~m}$ ) to pea size and diminishing as the eruption continued" (Baxter and Gresham, 1997; see Bruce, 2001 for an account of this eruption). Other examples are listed by Blong (1984) who further notes that separating projectilerelated casualties is rarely done in descriptions of volcanic eruptions, hence determining the number killed and injured by projectiles is not currently possible.

Due to the comprehensive information already available on projectile impacts for buildings (e.g. Fig. 2) and the inherent difficulties in estimating casualties (e.g. the result depends on the number of people outdoors), this discussion on tephra particle size suggests that the most significant research gains could be made by focusing on static tephra load leading to roof collapse rather than impact energy. Thus, this paper concentrates on an analysis of roof vulnerability to the static load imposed by tephra and consequent casualty estimates.

\subsection{Mechanisms of roof and building failure}

Tephra load can be considered a distributed gravity load, similar to snow. Roofs already designed for snow and other distributed loads can therefore be expected to have some inherent resistance to tephra loading. Design snow loads common in northern Europe, such as in the UK, are between 0.5 and $1.0 \mathrm{kPa}$. Some aspects of snow load, such as shedding of the load from steeply pitched roofs, and accumulation in hollows or against walls, are likely to occur under tephra loading too.

Even where snow load is not a usual design concern, roofs are sometimes designed for wind pressures or for some degree of access by people, even if only for periodic maintenance. These circumstances are likely to require a minimum imposed load which is again around 0.5 to $1.0 \mathrm{kPa}$, with much higher loads if the roof is flat and designed for normal access or storage. Some countries, for example Indonesia and Papua New Guinea, have significant tephra load hazards, but are outside the traditional tropical cyclone belts and hence have minimal wind loading codes for buildings.

Since building structures are provided with a reserve of safety beyond their rated design load, loads significantly greater than the design load are likely to be needed to cause some failure of the roof's structural system. Such failure could be limited to the roof or a roof component or could extend to the entire building. For most structural materials, any collapse of the roof structure is likely to occur only after substantial deformations have taken place. Potentially weak elements of typical sheet or tiled roofs are:
- The roof covering material (sheets or tiles) (Porter and Williams, 2000).

- The battens or rafters directly supporting these sheets.

- The purlins supporting the rafters.

- Trusses, where present, supporting the purlins.

The evidence from the studies in the Appendix seems to suggest that all these failure mechanisms have occurred, but that failure of the primary members - trusses or purlins - is most common, leading to the collapse of large areas of roof.

Structural failure under tephra load is not, however, confined to roofs, but can include supporting columns, walls, or foundations. Such failures can, unusually, be either due to the vertical structure being overloaded to failure before the roof fails or due to the horizontal load of ash collecting against a wall. More commonly, failure of the vertical structure is a secondary consequence of the initial roof collapse (Blong, 2003), due to either the connection of vertical and horizontal structure or unsupported lateral loads resulting from the roof collapse.

Thus, it would be reasonable to base an estimate of the structural vulnerability of most buildings to tephra load on the resistance of the roof to a distributed gravity load. This approach is taken in Sect. 3.

\subsection{Other types of building damage}

In addition to roof failure, tephra may cause building damage through:

- Early fallout from the plume of lithic and pumice blocks.

- Ingress of mud and debris following rainfall.

- Clogging of gutters and drains.

- Ingress of fine dust particles into buildings through ventilation holes or other openings.

- Accelerated corrosion of sheeting materials.

- Damage subsequent to the event, including water or floods, looting, or the absence of electrical services or proper drainage.

- Tephra-induced fire.

All forms of damage from tephra fall, structural or otherwise, could reduce a building's resistance to other hazards, volcanic or otherwise. No systematic studies of such phenomena were found in the published literature, but evidence from the Appendix provides anecdotal support. Examples (all from Blong, 1984) are:

- The tephra-induced fires in 1973 due to Eldfell erupting beside Heimaey, Iceland.

- Window and roof damage in a lookout hut from projectiles at Lassen Peak, California 1914-1915. 


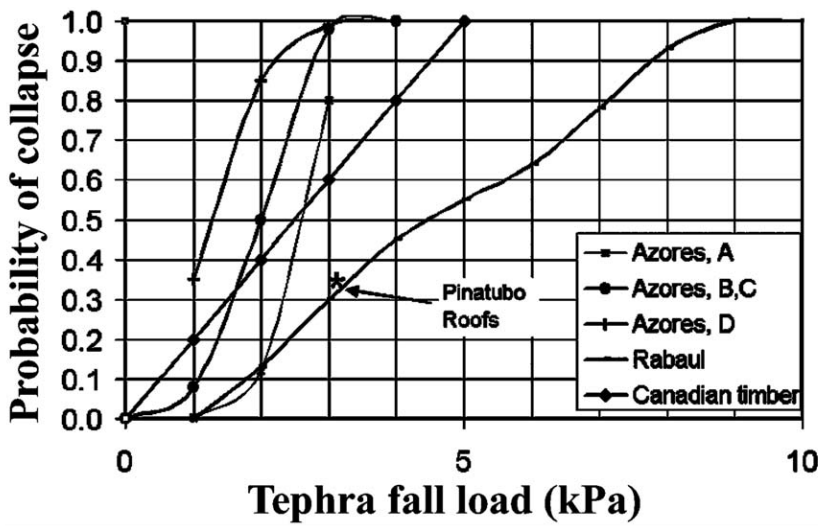

Fig. 3. Summary of available data on probability of roof collapse from tephra load. See text for references.

- Roof punctures in corrugated aluminium cladding from blocks ejected by Soufrière on Guadeloupe in 1976.

\subsection{Casualties}

The most common cause of death and injury associated with tephra falls has been roof collapse (Blong, 1984; see also the examples in the Appendix). When this occurs through the failure of a major structural element, the roof covering and the structural members supporting it will fall inwards along with the thick tephra layer above. Some of those trapped inside will be injured and/or asphyxiated by being buried under the sudden inrush of ash and the failed roof components. Distribution of deaths and injuries between these causes is not known, as no published studies were found of the causes of casualties in such collapses.

Some other causes of casualties associated with tephra falls have been noted:

- The direct impact of blocks and bombs on unsheltered people or crashing through windows.

- Death and injury occurring during the cleaning roofs during or after a tephra fall.

- Road accidents, such as vehicles skidding on wet ash.

These casualties are highly dependent on individual actions, such as driving during the eruption or choosing to clean roofs without adequate safety equipment.

Additional lethal and non-lethal medical effects result over the short-term and long-term from breathing in fine tephra particles (Blong, 1984). These effects include eye irritation, sore throats, upper respiratory tract infections, diarrhoea, bronchitis, and silicosis. Although some short-term and highly focused studies on tephra health effects exist (e.g. Baxter et al., 1989; Bernstein et al., 1986; Forbes et al., 2003; Hansell, 2003; Hickling et al., 1999; Ronan 1997, but see also Colquhoun's 1998 response; Samaranayake et al., 2004; Tobin and Whiteford, 2002), long-term, systematic studies of tephra-related health effects were not found. As Hickling et al. (1999) point out, discernable acute health effects are not always inevitable in a population affected by tephra.

Therefore, initial estimates of tephra-related deaths and injuries may reasonably be based on roof failure which has prior bases for analysis and which can be predicted, at least to the first order. The most comprehensive data available for casualties for roof failure, providing a reasonable starting point for this study, are estimates using the analogy of casualties from collapse of buildings in earthquakes (Coburn et al., 1992; Coburn and Spence, 2002).

\subsection{Summary}

Without forgetting the wider context as discussed in this section, the rest of this paper will focus on roof failure from the static load imposed by accumulating tephra. Casualties are considered from failure of roofs under this static load.

\section{Vulnerability assessment for roofs}

\subsection{Summary of previous studies}

Available vulnerability data from field or experimental work relating to damage probability to tephra load have been assembled and are summarised in Fig. 3.

The 3 Azores curves are from Pomonis et al. (1999). The failure loads were based on calculations supported by materials testing of typical roof timbers. The definitions of the 4 roof types are:

- Type Azores A: Roofs with rafters of $50 \times 75 \mathrm{~mm}$, spaced at $200 \mathrm{~mm}$ and spanning $2 \mathrm{~m}$ between purlins, of $100 \times 150 \mathrm{~mm}$ covered with boarding, old or new tiles, that were visibly in good condition $(50 \%$ of the total sample).

- Type Azores B: Roofs with rafters of $35 \times 55 \mathrm{~mm}$, spaced at $250 \mathrm{~mm}$ and spanning $1.35 \mathrm{~m}$ between purlins of $75 \times 125 \mathrm{~mm}$. Covered with boarding, new tiles or asbestos sheets, that were visibly in good condition $(25 \%$ of the total survey sample).

- Type Azores C: Roofs with rafters of $50 \times 75 \mathrm{~mm}$, spaced at $200 \mathrm{~mm}$ and spanning $2 \mathrm{~m}$ between purlins, covered with boarding, old tiles, that were as type A but visibly in poor condition (15\% of the total sample).

- Type Azores D: Roofs with rafters of $35 \times 55 \mathrm{~mm}$, spaced at $250 \mathrm{~mm}$ and spanning $1.35 \mathrm{~m}$ between purlins, covered with boarding, new tiles or asbestos sheets, that were as type B but visibly in poor condition (10\% of the total sample).

The Rabaul, Papua New Guinea curves are derived from data given by Blong (2003; see Table 2) and relate to the typical buildings of that town: virtually all had timber roof framing systems and a corrugated iron or ribbed metal sheet roof. The curves are derived from observed depths of tephra 
on buildings surveyed by insurance loss adjusters after the event, thus they overlook some buildings which failed totally and some buildings which were not insured. Thus, the sample is probably typical of the performance of the better-built buildings.

The curve for the Canadian timber roofs is derived from data given by Schreiver and Hansen (1964) showing that failure loads for conventional timber roof frames in Canada for laboratory-imposed roof loads ranged from 0.9 to $6.0 \mathrm{kPa}$. For comparison in the UK, BS 6399-3: 1988 is the relevant British Standard for imposed roof loads and suggests designing for minimum imposed uniform loads of $0.6 \mathrm{kPa}$ to $1.5 \mathrm{kPa}$, depending on the roof type.

A further piece of field data is from the Castellejos building survey (Sect. 2.2; Spence et al., 1996) where the tephra depth was about $200 \mathrm{~mm}$. Based on density estimates derived from samples taken at the Clark Air Base, the tephra fall imposed a load of about $3 \mathrm{kPa}$, resulting in the collapse or heavy damage of $33 \%$ of buildings in a sample of 51 surveyed (Table 1).

A wide spread of both estimated and observed roof vulnerabilities is evident from the data presented in Fig. 3. Generally, observed performance of roofs is better on average than performance estimated by calculation, perhaps because of the alternative load paths present in real roof structures.

\subsection{Studies of roof strengths in the Vesuvius area}

New work on roof vulnerability to tephra around the Vesuvius area in southern Italy has been completed. The Vesuvius Emergency Plan (Department of Civil Protection, 2001) currently estimates the probability of roof collapse according to critical resistance values. These are resistance thresholds above which the number of collapses of a given roof typology would be large enough to cause a serious problem for emergency management. These values, as defined by an expert group, are currently taken as $200 \mathrm{~kg} / \mathrm{m}^{2}, 300 \mathrm{~kg} / \mathrm{m}^{2}$, $400 \mathrm{~kg} / \mathrm{m}^{2}$ for wood, steel joist, and reinforced concrete slab roofs respectively. These resistance thresholds were used to define boundary limits in the yellow area (for evacuation planning around Mt. Vesuvius) for different roof structural typologies (Department of Civil Protection, 2001).

To contribute to the development of an improved understanding of roof resistance, roof vulnerability functions for different structural types in the Vesuvian area were estimated by a new approach. Coppa et al. (2004) propose a method of analysis based on theory developed by James et al. (1993) and applied by others (Ivanovic et al., 2000). The method analyses the spectral vibrations as a result of ambient noise and looks for a correlation with the structural characteristics defining roof strength.

In order to apply this method to Vesuvian roofs, a set of experiments was conducted on real roof structures. By this means, the degradation of structural materials over time and the effects of non-structural materials such as mortar, plaster, and tile were factored into the analysis. Eighteen flat roofs of different forms of construction were used.
Tests 1 through 9 were on tile lintel floor (reinforced concrete) of $25 \mathrm{~cm}$ thickness plus $2 \mathrm{~cm}$ of mortar and $2 \mathrm{~cm}$ of tiles. Tests 1 through 6 were on floors in poor condition while tests 7 through 9 were on floors in good condition. Tests 10 through 16 were on SAP floors (described in detail later) of $24 \mathrm{~cm}$ thickness, plus $2.5 \mathrm{~cm}$ of mortar and $2.5 \mathrm{~cm}$ of tiles. Tests 17 and 18 were on floors made with steel beams spaced $60 \mathrm{~cm}$, with insulated terracotta tile and light concrete.

In general, the natural frequency, $f$, of a horizontal single span slab can be calculated from:

$f=\frac{\alpha}{2 \pi L^{2}} \sqrt{\frac{E I}{\gamma}}$

$E=$ Young's modulus (Pa), $I=$ Moment of inertia $\left(\mathrm{m}^{4}\right)$, $L=$ Span (m), $\alpha=$ Coefficient relating to the end joint restraints (dimensionless), and $\gamma=$ Mass per unit length $(\mathrm{kg} / \mathrm{m})$.

Once the frequency is known from experimental studies, the unknown parameters in Eq. (2) are the stiffness, $E I$, and the end joint restraint parameter, $\alpha$.

The end joint restraint parameter $\alpha$ for each slab can be determined with a static test. Once this is determined, vibration analysis can be used to determine the stiffness for each roof. The static test cannot, however, be used to determine the stiffness, because of the transverse spread of the load.

For each roof, a full-scale static test with multiple displacement sensors was carried out. The deformed shape of the slab was used to determine the end joint restraint parameter $\alpha$. Subsequently, each roof was subjected to a dynamic test, using ambient vibrations, with accelerometers determining the response. From the peak values of the responses, the natural frequency of the first vibration mode, $f$, was determined. Using the value of $\alpha$ determined by the static test, Eq. (2) was then used to determine the stiffness of the slab assembly. The process is described in more detail in Coppa et al. (2004). This actual total stiffness of the existing structure is designated $(E I)_{a}$.

The original stiffness of the assembly can be estimated by calculation using data about materials and the dimensions of the different components. Values of Young's modulus $E$ are estimated from published data on the materials used (both structural and non-structural), while the value of the moment of inertia $I$ is determined from the shape of the cross-section and the thickness of the various layers. This "theoretical" original stiffness is designated $(E I)_{o}$.

The ratio $(E I)_{a} /(E I)_{o}$ can be described as a stiffness decay index and it is expected to be $<1$. Values of this index for the 18 slabs are shown in Fig. $4 \mathrm{~b}$. They vary from 0.4 to 1.0 .

The actual stiffness of the structural part of the slab in its existing state $(E I)_{s}$ can also be estimated by calculation, using the cross-section of the structural part, a value of the elastic modulus for the concrete taken from laboratory tests on concrete samples taken from the structure, and the well-defined value of elastic modulus for the steel. The ratio $(E I)_{a} /(E I)_{s}$ is a measure of the stiffness increment produced by the non-structural materials and is expected to be 
Table 3. Parameters used to evaluate the lower and the upper limit of roof resistance for each typology.

\begin{tabular}{|c|c|c|c|c|c|c|c|c|c|c|c|c|}
\hline \multirow[b]{2}{*}{ Type } & \multirow[b]{2}{*}{$\begin{array}{l}w \\
(\mathrm{kPa} \\
\left.\left(\mathrm{N} / \mathrm{m}^{2}\right)\right)\end{array}$} & \multicolumn{5}{|c|}{ Lower Limit } & \multicolumn{5}{|c|}{ Upper Limit } & \multirow[b]{2}{*}{$\begin{array}{l}Q_{\text {mean }} \\
(\mathrm{kPa})\end{array}$} \\
\hline & & $\begin{array}{l}M \\
(\mathrm{kNm} / \mathrm{m})\end{array}$ & $\delta$ & $\beta$ & $L(\mathrm{~m})$ & $\underset{(\mathrm{kPa})}{Q_{\text {lim }}}$ & $\begin{array}{l}M \\
(\mathrm{kNm} / \mathrm{m})\end{array}$ & $\delta$ & $\beta$ & $L(\mathrm{~m})$ & $\begin{array}{r}Q_{\text {lim }} \\
(\mathrm{kPa})\end{array}$ & \\
\hline $\begin{array}{l}\text { Wooden pitched roof } \\
\text { and flat iron. }\end{array}$ & 5 & 1 & 8 & 1.0 & $1^{*}$ & 2 & 1.5 & 8 & 1.0 & $1^{*}$ & 7 & 4.5 \\
\hline $\begin{array}{l}\text { Reinforced concrete } \\
\text { SAP. }\end{array}$ & 5 & 9 & 12 & 1.2 & 6 & $<0$ & 12 & 16 & 1.5 & 4 & 10 & 5 \\
\hline $\begin{array}{l}\text { Reinforced concrete } \\
\text { older than } 20 \text { years. }\end{array}$ & 5 & 17.5 & 12 & 1.2 & 6 & 2 & 22.5 & 16 & 1.5 & 4 & 25 & 13.5 \\
\hline $\begin{array}{l}\text { Reinforced concrete } \\
\text { younger than } 20 \text { years } \\
\text { or steel beam with } \\
\text { reinforced concrete } \\
\text { slab. }\end{array}$ & 5 & 22.5 & 12 & 1.2 & 6 & 4 & 27.5 & 16 & 1.5 & 4 & 35 & 20 \\
\hline $\begin{array}{l}\text { Reinforced } \\
\text { concrete pitched roof }\end{array}$ & 5 & $30^{* * *}$ & 12 & 1.2 & 6 & 7 & $40 * *$ & 16 & 1.5 & 4 & 50 & 28.5 \\
\hline
\end{tabular}

* Distance between the beam. In this case, the collapse is due to the failure of infill material between the iron beams.

$* \mathrm{M}$ is strengthened by axial stress.
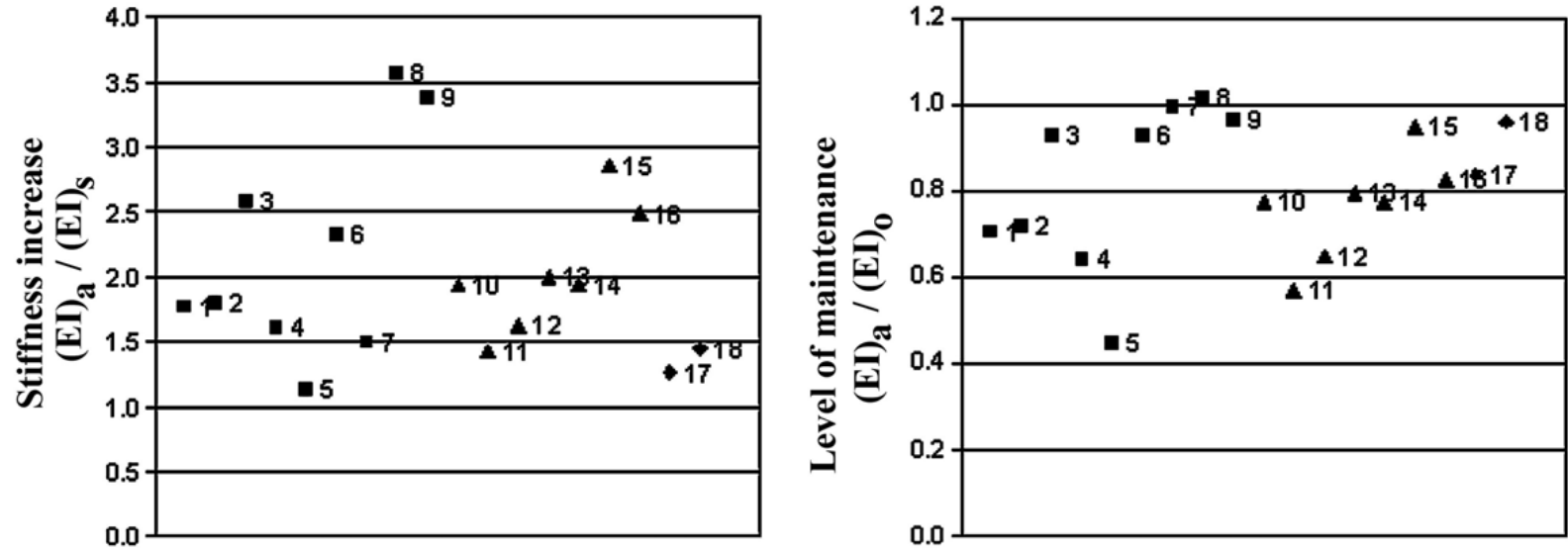

The numbers beside the symbols refer to the test numbers. The symbols are: $\square$ reinforced concrete $\star$ SAP $\bullet$ steel

Fig. 4. Experimental results from individual tests of deviations from the theoretical stiffness due to non-structural material ((a) left) and material degradation ((b) right). Each point represents a separate tested roof.

$>1$. Values of this index for the 18 slabs are shown in Fig. 4a.

They range from 1.0 to 3.5 .

These test results were used to improve earlier estimates of the limit load resistance of the roof structures. Any stiffness increment due to non-structural materials can be correlated with an increment in the limit resistance. Generally, the limit resistance is a linear function of the structural depth while the stiffness is a cubic function of the structure depth. Therefore, a reasonable assumption is that the limit resistance increment is approximately the cube root of the stiffness increment (James et al., 1993). This assumption was used to make an estimate of actual roof resistances in the Vesuvian area. A factor $\beta$ between 1.0-1.5 corresponding to the cube root of the stiffness increment for non-structural materials ranging between 1.0-3.0 (Fig. 4a) was therefore used in these calculations.

The limiting imposed load per unit area on a slab $Q_{l i m}$ can now be calculated from:

$Q_{\text {lim }}=\frac{\delta \beta M}{L^{2}}-w$

$M=$ Per unit slab width, the limit bending moment in the span's centre which factors in the decay of mechanical properties due to ageing $(\mathrm{Nm} / \mathrm{m}), Q_{\text {lim }}=$ Limiting tephra load on the slab per unit area, for roof failure $(\mathrm{Pa}), w=$ Slab's weight 
Table 4. Parameters to estimate roof collapse probabilities for Vesuvian roof types.

\begin{tabular}{lll}
\hline Type & $Q_{\text {mean }}(\mathrm{kPa})$ & $Q_{\text {dev }}(\mathrm{kPa})$ \\
\hline Wooden pitched roof and flat iron. & 4.5 & 0.9 \\
Reinforced concrete SAP. & 2.5 & 0.5 \\
Reinforced concrete older than 20 years. & 9.5 & 1.9 \\
Reinforced concrete younger than 20 years or steel beam with reinforced concrete slab. & 13.5 & 2.7 \\
Reinforced concrete pitched roof. & 20 & 4 \\
\hline
\end{tabular}

per unit area $\left(\mathrm{Pa}\left(\mathrm{N} / \mathrm{m}^{2}\right)\right), \beta=\mathrm{Increase}$ of strength induced by non-structural layers, estimated from dynamics tests of the natural vibration frequencies of horizontal spans of different roof materials as described above (dimensionless), and $\delta=$ Coefficient relating to the extreme joint restraints and reinforcements, dependent on values of the limit bending moment at the joints and the span's centre. Ranges from 8 (end free to rotate) to 16 (ends fully fixed or continuous) (dimensionless).

For different roof materials, lower and higher limit loads have been calculated (Table 3 ). For all slab types, a value of self weight, $w=5 \mathrm{kPa}\left(\mathrm{kN} / \mathrm{m}^{2}\right)$ has been used.

Based on this analysis, the probability of collapse is calculated from:

$p($ collapse $)=\Phi\left(Q_{\text {mean }}, Q_{\text {dev }}\right)$

$Q_{d e v}=$ Standard deviation of the limiting load on the slab per unit area $(\mathrm{Pa}), Q_{\text {mean }}=$ Mean value of the limiting load on the slab per unit area $(\mathrm{Pa})$, and $\Phi=$ The cumulative normal distribution with mean value $Q_{\text {mean }}$ and standard deviation $Q_{\text {dev }}$.

Proposed values for $Q_{\text {mean }}$ and $Q_{\text {dev }}$ for each of 5 classes of roof are given in Table 4. For all classes of Vesuvian roofs, $Q_{d e v}$ is assumed to be $20 \%$ of $Q_{\text {mean }}$. This figure is based on the authors' judgement from observed roof performance, rather than on a satisfactory statistical sample. The assumed variation allows for uncertainty in the resistance of materials, of structural dimensions, and of load paths, present to an equal extent in roofs of all types.

SAP roofs must be considered as a separate case. The SAP floor technique, a cheap form of reinforced concrete construction, was commonly constructed in the 1940s and 1950 s in Italy, especially in the south. SAP floors were constructed from an assembly of preformed beams made from terracotta blocks through which reinforcing bars had been threaded to achieve continuity. In situ concrete formed a topping layer and was also intended to anchor the bars in the terracotta blocks and into the supporting beams. In many cases, the concrete was unable to reach and protect the bars inside the blocks. Weather-related water infiltration at the top floor or pipe-failure-related water infiltration in lower floors has in some cases caused corrosion in the bars, as has concrete carbonation. Consequently, these structures are liable to undergo fragile shear collapse mechanisms at low additional loads. Spontaneous collapse of SAP roofs has been observed implying that, for this study, SAP roofs have a nonzero probability of failure for negligible overload. Around the Vesuvius area, just under $10 \%$ of roofs, representing $15 \%$ of reinforced concrete buildings, are SAP reinforced concrete slabs.

From these results, it can be concluded that the replacement of the three weakest roof types - wooden pitched roofs, steel joists, and reinforced concrete SAPs - would represent a significant improvement in overall roof strength around the Vesuvius area.

\subsection{European tephra fall roof vulnerability curves}

The data shown in Fig. 3 and Table 3 suggest that while the strengths of the weakest roofs are predicted reasonably well by calculations, the strongest roofs can be considerably stronger than calculations would predict. For example, whereas sheet roofs are typically designed for no more than 1 or $2 \mathrm{kPa}$ load, in Rabaul some roofs survived loads of $7 \mathrm{kPa}$ without collapse. Therefore, the resistance of roofs to tephra fall loads can be more variable than predicted by calculation and calculated vulnerability distributions should be modified to allow for the over-strength found in real situations. A new proposal for a classification of European roofs and associated vulnerability functions is now developed.

One of the aims of the E.U.-funded EXPLORIS project (Explosive Eruption Risk and Decision Support for EU Populations Threatened by Volcanoes, EVR1-2001-00047) from 2002-2005 is to develop an engineering approach to risk mitigation for volcanic areas in the E.U. threatened by explosive eruptions. Using four European volcanoes as reference sites - Vesuvius in Italy, Sete Cidades in the Azores, Soufrière in Guadeloupe, and Teide in the Canary Islands - the EXPLORIS project team is investigating methods to model, assess, and mitigate the impacts of different explosive eruption scenarios. Tephra fall is only one of the possible volcanic hazards being considered. Others include pyroclastic flows and earthquakes.

Extensive building surveys in the Vesuvian area have been carried out in recent years, to identify vulnerability to tectonic earthquake as well as to volcanic hazards (Zuccaro, 2000; Spence et al., 2004). Today, around $70 \%$ of the population live in apartment blocks, mostly constructed in the postwar period. These are of reinforced concrete frame construction, with reinforced concrete slab roofs and floors, normally 
(a)

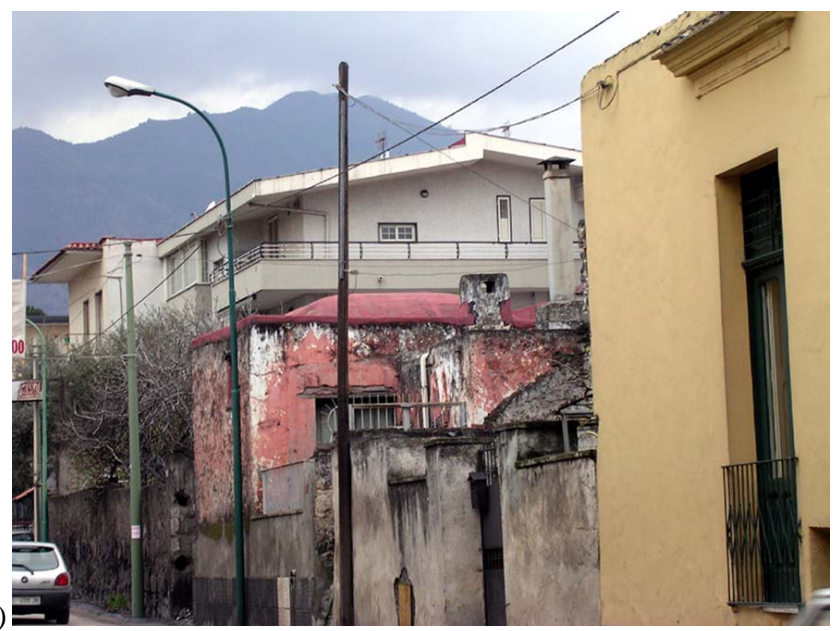

(b)

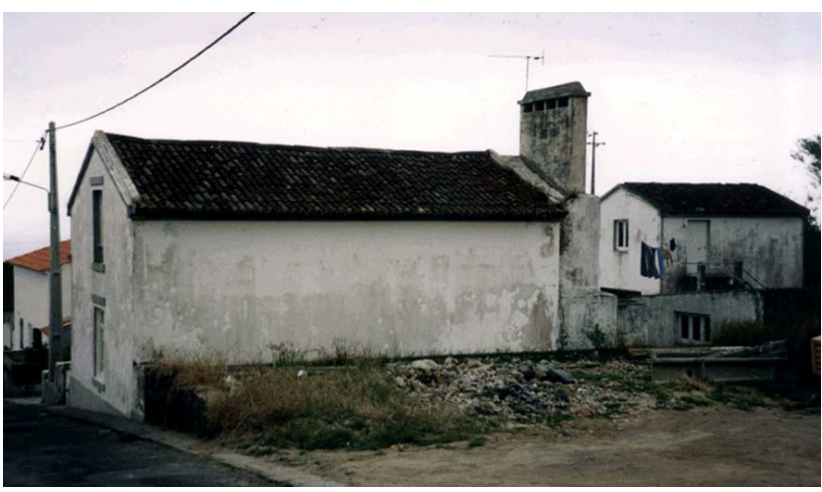

(c)

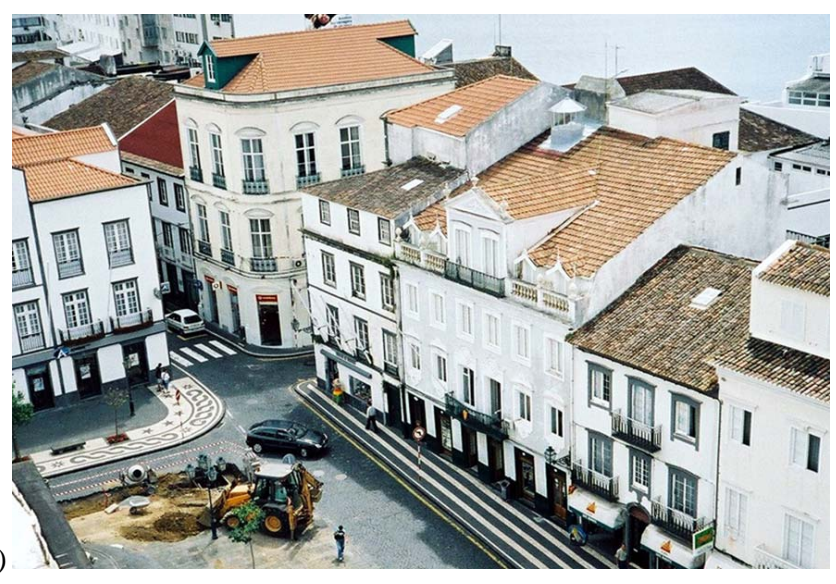

(d)

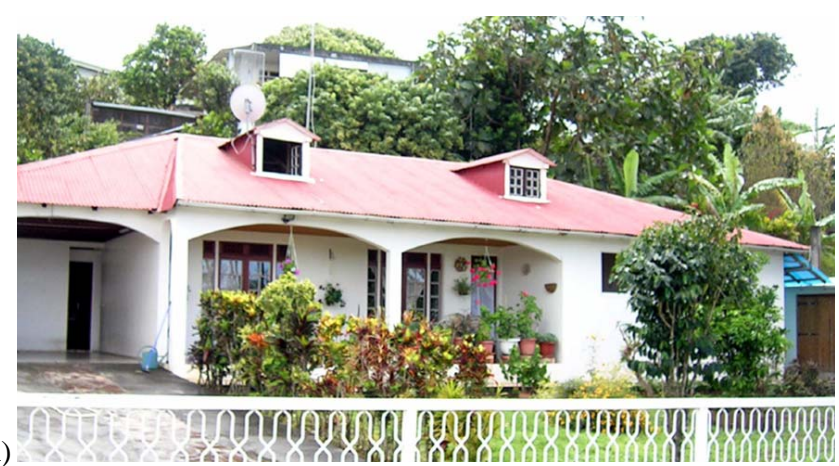

(e)

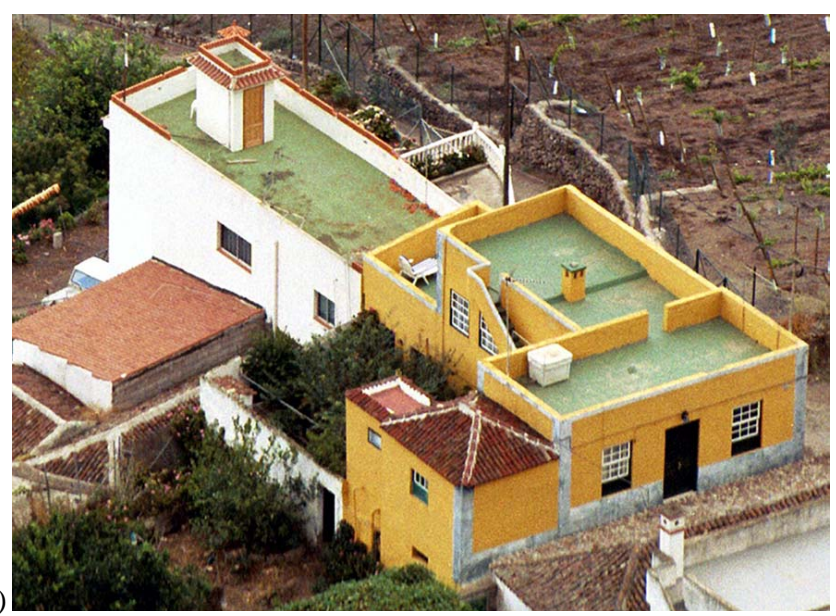

Fig. 5. Roof construction types in the 4 volcanic areas. (a) Vaulted and reinforced concrete roofs near Vesuvius; (b) Tiled roof in Candelária, rural Azores; (c) Tile roofs in Ponta Delgada, Azores; (d) Metal sheet roof in Guadeloupe; (e) slab roof terrace in Icod de los Vinos, Tenerife.

designed for access. However, a significant number of buildings from earlier periods still exist. Those built before the beginning of the 20th century, inhabited by about $16 \%$ of the population, would originally have had roofs of masonry vaulted construction; but few of these remain (an existing example from Terzigno is shown in Fig. 5a), and the older buildings now have pitched tiled roofs of timber construc- tion, flat terrace roofs of steel joists covered with concrete, or modern reinforced concrete slabs.

Those built in the early 20th century may also have originally had vaulted roofs, but these have now been replaced by reinforced concrete roofs or by steel trusses supporting tiled roofs. Design loads for flat terrace roofs in the post-war period are typically $2 \mathrm{kPa}$, and roofs are expected to be designed 
Table 5. Proposed classification of European roof types for tephra fall resistance.

\begin{tabular}{|c|c|c|c|}
\hline Roof Class & Description & $\begin{array}{l}\text { Typical design } \\
\text { load range }\end{array}$ & $\begin{array}{l}\text { Mean collapse } \\
\text { load }\end{array}$ \\
\hline $\begin{array}{l}\text { WE } \\
\text { (weak) }\end{array}$ & $\begin{array}{l}\text { Sheet roofs, old or in poor condition. } \\
\text { Tiled roof, old or in poor condition. } \\
\text { Masonry vaulted roof. }\end{array}$ & $\begin{array}{l}\text { Pre-design code, or } \\
\text { no design code. }\end{array}$ & $2.0 \mathrm{kPa}$ \\
\hline $\begin{array}{l}\text { MW } \\
\text { (medium } \\
\text { weak) }\end{array}$ & $\begin{array}{l}\text { Sheet roof on timber; average quality; average or good quality tiled roof } \\
\text { on timber rafters or trusses. } \\
\text { Steel or precast reinforced concrete joists and flat terrace roof. }\end{array}$ & $1-2 \mathrm{kPa}$ & $3.0 \mathrm{kPa}$ \\
\hline $\begin{array}{l}\text { MS } \\
\text { (medium } \\
\text { strong) }\end{array}$ & $\begin{array}{l}\text { Flat reinforced concrete roof not all above characteristics; sloping rein- } \\
\text { forced concrete roof. } \\
\text { Sheet roof on timber rafters or trusses, good quality and condition, de- } \\
\text { signed for cyclone areas. }\end{array}$ & $2-3 \mathrm{kPa}$ & $4.5 \mathrm{kPa}$ \\
\hline $\begin{array}{l}\text { ST } \\
\text { (strong) }\end{array}$ & $\begin{array}{l}\text { Flat reinforced concrete roof designed for access; recent, good quality } \\
\text { construction, younger than } 20 \text { years. }\end{array}$ & $>3 \mathrm{kPa}$ & $7.0 \mathrm{kPa}$ \\
\hline
\end{tabular}

for a basic dynamic pressure of $1.0 \mathrm{kPa}$ (Decreto Ministeriale 3 October 1978 and Decreto Ministeriale 26 March 1980), corresponding to a wind speed of around $40 \mathrm{~m} / \mathrm{s}$, with various modifying coefficients according to building size and height.

For the Azores, field surveys of buildings in São Miguel were carried out by Pomonis et al. (1999), and, more recently and much more extensively by the Centro de Vulcanologia e Avaliação de Riscos Geológicos, Universidade dos Açores (Centre of Volcanology at the University of the Azores). In the rural areas closest to the Sete Cidades volcano, a high proportion of residential buildings consists of individual family houses, built of masonry, of one or two storeys, with tiled roofs supported by a timber substructure trusses and rafters and boarding (Fig. 5b). A few roofs are flat, with a reinforced concrete slab, and a few have asbestos-cement sheet roofs. The timber roofs have a variety of structural forms, and a range of ages, giving rise to a range of expected levels of resistance to vertical loads. In Ponta Delgada, the Azorean capital, which is also within range of tephra fall from Sete Cidades, building types are more mixed (Fig. 5c). There is still a predominance of pitched tiled roofs of various ages, but reinforced concrete apartment blocks with flat roofs are common and some sheet roofs and long-span roofs are found.

Building surveys in Guadeloupe were conducted in 2004 as a part of the EXPLORIS project, concentrated in the settlements closest to Soufrière volcano: Basse-Terre, the département's capital, and the adjoining commune St. Claude. In this tropical climate, a tendency exists for buildings to be relatively widely spaced and they traditionally have had more lightweight roofs than in the other volcanic regions studied (Fig. 5d). Following a devastating hurricane in 1928, from 1930 to 1970, reinforced concrete frame buildings with flat roofs were commonly built. The earlier tradition, which is again the norm in recent years, is for roofs to be of shallowpitched metal sheets supported by timber framing, or more recently sometimes by steel trusses. In the centre of Basse-
Terre town, houses rise to 3 storeys, with pitched tile roofs, and there are some multi-storey apartment blocks with concrete frame construction and slab roofs. Throughout the area, roofs built after 1930 will be designed to withstand tropical cyclones, which implies uplift forces on the relatively shallow pitched roofs of $2 \mathrm{kPa}$ or more, substantially greater than their weight, and implying a need for effective ties to the walls and ground.

Building surveys in Tenerife were also carried out in 2004 as a part of the EXPLORIS project, focusing on the municipality of Icod de los Vinos, the steep slopes of which would likely be impacted by tephra in most expected explosive volcanic scenarios for the island. Residential buildings ranged from adjoining blocks in urban areas to well-spaced houses in the centre of their own plot in rural areas. Concrete frame, squared masonry, and rubble masonry accounted for almost all buildings. The majority of roofs surveyed were flat concrete with a finish permitting their use as a terrace for recreation and drying laundry (Fig. 5e). The remainder of roofs were mixed, including a pitched tile-on-timber roof for older buildings and flat, terraced roofs supported by timber joists. Finishes include tiles and sheeting.

Based on these recent field studies and the data in Fig. 3 and Table 3, a new classification of roof structures is proposed, based on their probable resistance to tephra fall loads. The aim is to define a set of standard vulnerability classes of roofs, each with its own characteristic vulnerability curve. It was decided that 4 classes would be defined initially. The data presented in Fig. 3 suggest that the resistance of most roofs falls between 1 and $8 \mathrm{kPa}$. Thus, the classes have been defined such that the average roof resistances of the 4 classes are equally spaced on a logarithmic scale of resistance, with the weakest (WE) having an average resistance of $2 \mathrm{kPa}$ and the strongest (ST) having an average roof resistance of $7 \mathrm{kPa}$. The other 2 classes (MW and MS) therefore have average resistances of $3 \mathrm{kPa}$ and $4.5 \mathrm{kPa}$ respectively. 
Table 6. Distributions of roofs in the proposed composite European tephra fall vulnerability curves.

\begin{tabular}{llll}
\hline \multirow{2}{*}{ Roof Class } & $10 \%$ exceedence & $50 \%$ exceedence & $90 \%$ exceedence \\
\cline { 2 - 4 } & $p=0.05$ & $p=0.30$ & $p=0.70$ \\
\hline WE (weak) & $85.7 \%$ of roofs & $34.3 \%$ of roofs & $2.7 \%$ of roofs \\
MW (medium weak) & $13.5 \%$ of roofs & $44.1 \%$ of roofs & $18.9 \%$ of roofs \\
MS (medium strong) & $0.7 \%$ of roofs & $18.9 \%$ of roofs & $44.1 \%$ of roofs \\
ST (strong) & $<0.1 \%$ of roofs & $2.7 \%$ of roofs & $34.3 \%$ of roofs \\
\hline
\end{tabular}

$p$ represents the probability that each trial for determining the binomial distribution is true.

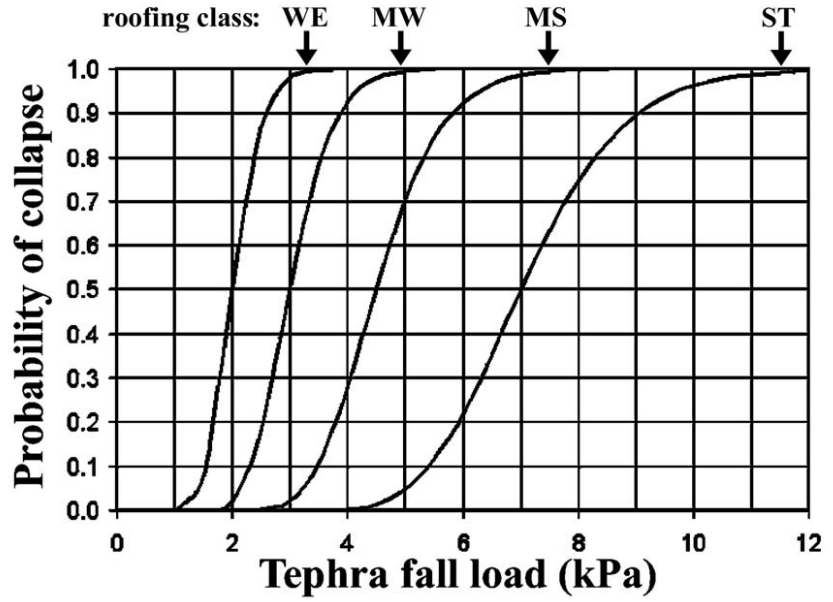

Fig. 6. Tephra fall roof vulnerability curves for the European roof classes described in Table 5. From left to right, classes WE, MW, MS and ST.

This classification is shown in Table 5. The vulnerability curve for each class was then defined (Fig. 6) as having a cumulative lognormal distribution with a coefficient of variation of $20 \%$, giving a similar dispersion to the Vesuvian roofs (Sect. 3.2).

Each of the roof types observed in the field has been assigned a vulnerability class, based on the authors' judgement of the roof resistances derived from design regulations, conventional practice, and the observed age and condition. Where a roof type observed in the field is thought to span more than one vulnerability class, an allocation of the roofs of that type between 2 or more vulnerability classes has been made, again based on the authors' assessment.

The field survey experience indicated that distinguishing different roof types in a large population of buildings can be difficult. A method was developed to calculate a probable mean value and likely $10 \%$ and $90 \%$ bounds for the proportion of collapsed roofs in the residential building stock (Fig. 7).

The roofs of any region may be assumed to be distributed amongst the four roof classes according to a binomial distribution. The results of the calculations are listed in Table 6 on the basis of three different assumptions about the p-value for the binomial distribution. As Table 6 shows, the $90 \%$ exceedence probability curve is based on a building stock

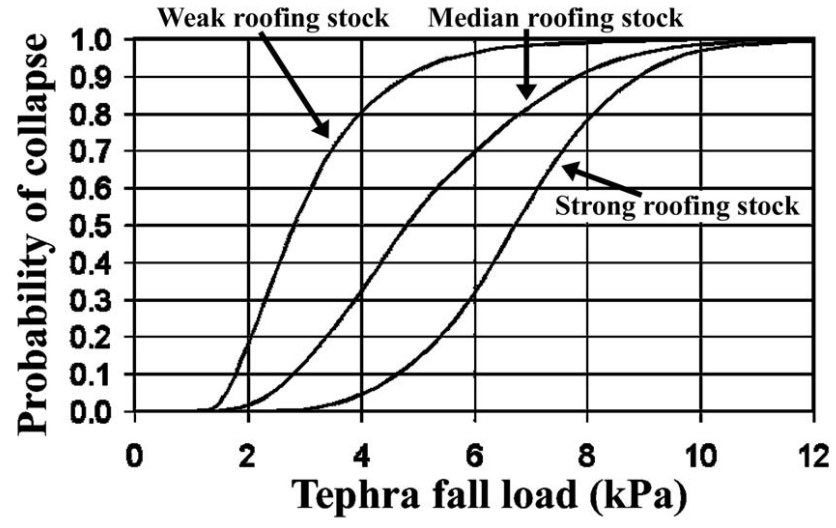

Fig. 7. Proposed composite European tephra fall vulnerability curves, based on assumed distributions of the building stock shown in Table 6. From left to right, weak roofing stock, median roofing stock, and strong roofing stock.

which contains a high proportion of modern (Class ST) roof types and the $10 \%$ exceedence probability curve is based on a building stock which contains a significant proportion of older roofs (Classes WE and MW) with few modern roofs. These distributions are derived from observations of roof types in several surveys in European building stocks, including the four surveys carried out for the EXPLORIS volcanoes.

Figure 7 was then drawn based on assumed distributions of the building stock between the different classes as shown in Table 6. The curves in Fig. 7 would be suitable for preliminary assessments of likely collapse rates and human casualty estimates at a site where no information was available on the distribution of roof types.

\subsection{Human casualty implications of roof collapse}

Casualty consequences of roof collapse in São Miguel have been considered by Pomonis et al. (1999). Their estimates are based on evidence from several eruptions including photographic evidence from the Mt. Pinatubo eruption in 1991, but also considering earthquake analogies (Coburn et al., 1992; Coburn and Spence, 2002). In the São Miguel region at risk, most buildings were single- or two-storey with almost none higher than three storeys. The likely rate of injury and fatality occurrence was assumed to be: 
- Single-storey buildings: one third of occupants entrapped, of which half will be injured and half killed due to either suffocation or impact by falling debris.

- Two- or three- storey buildings: $10 \%$ of occupants entrapped, of which half will be injured and half killed due to either suffocation or impact by falling debris.

Around Vesuvius, repeated historical evidence exists of roof collapse under tephra loads and associated fatalities, notably in Herculaneum and Pompeii in A.D. 79 and in Ottaviano and San Guiseppe in 1906 (Blong, 1984). The buildings would have been mostly single- or two-storey, but many of the roofs would have been masonry vaults, the failure of which would have caused multiple injuries as well as asphyxiation.

Today's building stock around Vesuvius contains few vaulted roofs, a diminishing number of roofs supported by timber trusses, and a majority of roofs with steel joists or reinforced concrete slabs. Multi-storey buildings are common. Again based on earthquake analogies (Pomonis et al., 1999), the following assumptions are proposed for death and injury related to roof collapse in the Vesuvian area:

- Single-storey buildings: One third of occupants of the whole building trapped, of which half are killed and half are seriously injured.

- Two-storey buildings: $10 \%$ of occupants of the whole building trapped, of which half are killed and half are seriously injured.

- Three or more storeys: $20 \%$ of those on the top floor trapped, of which half are killed and half are seriously injured.

For multi-storey buildings, deaths and injuries are therefore assumed to be confined to the top floor only. Some deaths and serious injuries would occur as a result of other tephra-related causes, such as falling while clearing roofs, but these would not likely be many compared to the roof collapse casualties. In multi-storey buildings, the potential exists for lives to be saved by evacuating people from the top floor, but this has not been accounted for here. Progressive collapse, where a roof collapse leads to collapse of the floor below and down through the building is possible for some structural systems, but is considered unlikely in the kind of frame structures typical of the buildings in the Vesuvian area.

For other areas, the estimated casualty rates would depend on the buildings and their roofs. For many areas potentially threatened by tephra in the EU, the Azores estimates would serve as a reasonable starting point for rural areas while the Vesuvius estimates would serve as a reasonable starting point for urban areas. Nonetheless, the estimates may need to be refined according to observations in a specific location.

\section{Mitigation}

Mitigation options need to be considered in 3 categories:
- Codes of practice for new construction.

- Modifications of existing buildings.

- Emergency procedures.

Some possible considerations are described in the next sections.

\subsection{Codes of practice}

For new buildings, the most straightforward mitigation measure would be to make roofs stronger. Based on the vulnerability curves presented in this paper, it is suggested that roofs should be designed for a tephra load based on $10 \%$ probability of exceedence in 50 years, a design basis which is now commonly used to design for earthquake ground shaking (Kircher and Hamburger, 2000). For any volcanic area, the design load could be based on tephra fall maps for a 500year eruption scenario. Such buildings should not be considered "tephra safe" or even completely "tephra resistant", but they would afford a standard of protection which would withstand the static loading from majority of tephra falls expected in populated areas.

Changing the roof's angle or shape to encourage tephra to slide off rather than to accumulate would be an option. This design change is less desirable than strengthening roofs because the effect of roof's angle on tephra accumulation is surprisingly poorly understood. Furthermore, many regions could have cultural, materials, construction capability, or aesthetic restrictions on altering the roof shape currently used.

Designing ventilation openings to reduce ash infiltration would help to protect health, systems, and property inside a building. Due to the small particle sizes present in tephra, the most appropriate approach would be to design ventilation openings which can be mechanically sealed and to maintain those mechanisms. Other suggestions for buildings include "snap-off awnings and gutters independent of main building frame" and "utilize underground electrical supply" (Blong, 2000 focusing on Rabaul).

To protect against failure due to tephra accumulating alongside a building, the structure could be raised or walls could be thickened or better supported, but little evidence of such problems in the past exists. In considering the potential for new issues to arise, such as lateral collapse of a structure due to accumulating tephra, care must be taken that other vulnerabilities are not exacerbated. For example, for Rabaul, Blong (2000) describes a building code which suggests raising floor levels by $0.3 \mathrm{~m}$ or more to avoid tephrarelated mudfill damage. A properly-braced raised structure might provide adequate protection from lahars and volcanic floods; however, if stilts were used and if they were poorly braced, the structure could collapse under low flow or lateral tephra loads. As well, lahars can be highly erosive and can transport boulders threatening even properly-braced raised structures.

The impacts on social vulnerability of any code changes would need to be considered. For example, building struc- 
tural flood defences encourages people to build in floodprone areas thereby often increasing overall flood risk and resulting in much greater flood disasters if the defences subsequently fail (e.g. Etkin, 1999; Fordham, 1999; Kelman, 2001). Similarly, suggesting that a new code provides tephraresistant houses could encourage people to stay in their homes during a volcanic eruption, potentially exposing them to other life-threatening volcanic hazards. Any strategy to combat roof vulnerability to tephra should be linked to overall building safety including all volcanic and non-volcanic hazards threatening a community. Tephra-focused changes should not be enacted without considering this wider context.

\subsection{Modifications of existing buildings}

As with new buildings, the most straightforward mitigation measure for retrofitting existing buildings would be to make roofs stronger, according to the same design criterion proposed for new buildings in Sect. 4.1. The same provisos apply here as for new buildings. Since funds for such retrofitting would be limited, buildings designated as shelters or liable to be used as shelters - especially schools, hospitals, and religious centres - should take priority for retrofitting.

In case of imminent tephra threats not permitting the time to enact proper retrofitting, attempts could be made at propping up roofs temporarily:

"These [props] can be placed along the purlins and can be either from wooden rods or from adjustable metal scaffolding. The size and number of these props will be peculiar to each house. Measures to spread the load, using wooden pads at both ends, should also be taken. Every house could have these stocked in case of an eruption or when an eruption is threatened. Easy access to the roof [would need to be] available in every house, internally and externally, to achieve either of these two actions without difficulty (Pomonis et al., 1999)."

For reducing non-roof tephra damage, preventing tephra ingress into the building would be paramount. Openings, particularly those with glass, could be covered with strong material such as plywood or metal sheeting to prevent large clasts breaking through. Smaller openings such as the spaces underneath doors or cracks between a window frame and the wall could be sealed. In addition to preventing damage (e.g. to electrics, from bomb or block impact, or from subsequent fires) and to easing the post-eruption clean-up, these actions would reduce the tephra-related health risks of anyone remaining in the property. Completely sealing a property is unlikely to be successful, but the infiltration rate could be substantially reduced.

\subsection{Emergency management}

Community preparedness should be an integral part of emergency planning and risk reduction for large volcanic eruptions. The eruption of Pinatubo (1991) irrevocably changed attitudes towards mitigation by showing how lives could be unnecessarily lost through lack of awareness of the impacts of tephra fall, even though the at-risk population had been in a full state of preparation for an imminent, major eruption and the area around the volcano at risk from pyroclastic flows had been effectively evacuated. The eruption was accompanied by torrential rain from a passing typhoon, which mixed with the falling ash to form a mud of double the density of dry ash on top of roofs. Terrified, people had to shelter inside their buildings for hours with outside visibility reduced to near-zero. The weaker roofs eventually began to creak and snap as the supports broke followed by the deadly inrush of wet ash. Section 2.2 describes the consequences.

The fallout from most major explosive eruptions will be less hazardous than this extreme example, but certain key measures need to be considered. The eruption cloud from sub-plinian or plinian eruptions will contain lithics and pumice clasts of varying sizes which will fall out of the plume first and present an immediate risk of injury unless people rapidly take shelter inside robust buildings. This material will bombard roofs and even penetrate and damage weaker ones. As ash begins to fall, visibility drops. All movement under these conditions would be inadvisable as lights are rarely able to penetrate the gloom and breathing difficulties could result. Whilst the eruption lasts, the population should remain marooned inside buildings or vehicles. In lighter falls, driving is possible, but with fine ash, engine filters and windscreens are difficult to keep clean.

Cleaning ash off roofs when it is falling wet would be challenging and dangerous with the poor visibility and atrocious conditions. With dry ash, the particle levels in the air would be high and would obscure vision as well as the particles interfering with breathing and becoming foreign bodies in the eyes. Advice to occupants to remove ash during eruptions is likely to be misplaced. It could cause more deaths and injuries from falling off roofs than advising people to seek shelter in the nearest robust building and to avoid wide-span structures unless they are specifically designated as shelters.

This latter point deserves emphasis. Buildings with widespan roofs such as church halls and school gymnasiums are most likely to be used as emergency shelters and are natural locations for congregating. Unless they are specifically designed to withstand large loads, significant casualties could result from tephra-induced roof collapse during a volcanic eruption. Preventing people from entering these places during a crisis could be challenging. Thus, a strong need exists for civil defence authorities to address this issue long before the volcano erupts with the likely responses being raising awareness regarding appropriate shelters and strengthening the roofs of appropriate buildings.

Advising populations to evacuate a wide area around a volcano, possibly many tens of kilometres away from eruption centre, well in advance of an event is unlikely to be successful. But when an eruption is imminent it will be too late to attempt to drive away in case of becoming marooned in the ash fall. Detailed plans should therefore be drawn up on the feasibility of the population taking shelter in safest parts of the most resistant building typologies and to know what to 
do to either temporarily support the roof from inside or to escape before the roof collapses.

When the eruption is over, roofs will need to be rapidly repaired and ash should be cleared away from all other roofs in case there is a subsequent eruption which adds to the roof loading and leads to collapse. Householders and clean-up crews should be warned about the risk of injury from falls and on the need to take safety precautions.

If rainfall accompanies, or follows soon after, an eruption, local flooding may ensue in low-lying areas. On steep volcanic slopes lahars can readily form and run into inhabited areas to add to the hazards and the devastation.

Communications, like all forms of transport, are likely to be severely disrupted during heavy ash falls and planning needs to take this into account. Power supplies may short and fail, so houses can be out of electricity for hours or days until repair workers can get to the power lines and restore supplies.

\section{Conclusions}

Buildings, particularly roofs, are vulnerable to tephra fall from volcanic eruptions, therefore making the occupants vulnerable to tephra-induced injury or death. Roof construction type and failure mechanism are the principal factors which determine the tephra load which damages roofs or causes them to collapse. Previous field, experimental, and theoretical work suggests that many roofs would collapse under loads in the range $1-5 \mathrm{kPa}$ but field and other experimental work has shown that some designs can withstand up to $10 \mathrm{kPa}$ or more, beyond the theoretical range.

The main gaps in evidence and the literature are:

1. Understanding failure mechanisms of roofs of different forms of construction and the consequent causes of casualties.

2. Consistent empirical evidence, particularly collecting data needed to compare case studies.

3. Connecting the hazard, vulnerability, and impacts aspects of this risk, specifically a systematic approach to defining hazard, vulnerability, and impacts of tephra effects on buildings and people.

4. A framework or guidelines for exploring site-specific mitigation measures.

Further investigations should include systematic field studies of the effects of tephra on buildings other than the vertical load on roofs. More work on vulnerability reduction through education of populations at risk would also help to save lives (e.g. Simkin et al., 2001).

Additionally, it is important not to consider tephra in isolation from other volcanic hazards. In discussing Rabaul, Blong (2003) notes that "Rabaul experience also indicates that building codes for volcanic areas need to consider mudfills and post-eruption corrosion of sheet metal roofs and wall cladding. Most importantly, had the majority of buildings in Rabaul survived the September 1994 tephra falls, wet season mudflows a few months later would still have made most of the town unsafe and uninhabitable."

This paper has contributed towards filling in these gaps by developing composite vulnerability curves for the European building stock in areas potentially threatened by explosive volcanic eruptions. Preliminary approaches for estimating resultant casualties have also been suggested. Although more work remains to be completed, the basis for a method and initial results has been established.

\section{Symbols}

$E \quad$ Young's modulus (Pa)

$(E I)_{a} \quad$ Actual total stiffness of the existing structure $(\mathrm{N}$ $\mathrm{m}^{2}$ )

$(E I)_{o} \quad$ "Theoretical" original stiffness $\left(\mathrm{N} \mathrm{m}^{2}\right)$

$(E I)_{s} \quad$ The actual stiffness of the structural part of the slab in its existing state $\left(\mathrm{N} \mathrm{m}^{2}\right)$

$f \quad$ the natural frequency of a horizontal single span slab $\left(\mathrm{s}^{-1}\right)$

$g \quad$ Gravitational acceleration $\left(9.80665 \mathrm{~m} / \mathrm{s}^{2}\right)$

$h \quad$ Tephra thickness or depth (m)

I Moment of inertia $\left(\mathrm{m}^{4}\right)$

$L \quad$ Slab's span (m)

$M \quad$ Per unit length, the limit bending moment in the span's centre which factors in the decay of mechanical properties due to ageing $(\mathrm{Nm} / \mathrm{m})$

$p \quad$ Represents the probability that each trial for determining the binomial distribution is true (dimensionless)

$Q_{\text {dev }} \quad$ Standard deviation of the limiting load on the slab per unit area $(\mathrm{Pa})$

$Q_{\text {lim }} \quad$ Limiting load on the slab per unit area $(\mathrm{Pa})$

$Q_{\text {mean }}$ Mean value of the limiting load on the slab per unit area $(\mathrm{Pa})$

$w \quad$ Slab's weight per unit area $\left(\mathrm{Pa}\left(\mathrm{N} / \mathrm{m}^{2}\right)\right)$

$\alpha \quad$ Coefficient relating to the extreme joint restraints and reinforcements (dimensionless)

$\beta \quad$ Increase of strength induced by non-structural layers, estimated from dynamics tests of the natural vibration frequencies of horizontal spans of different roof materials (dimensionless)

$\gamma \quad$ Slab's mass per unit length $(\mathrm{kg} / \mathrm{m})$

$\delta \quad$ Coefficient relating to the extreme joint restraints. and reinforcements, dependent on values of the limit bending moment at the joints and the span's centre. Ranges from 12 to 16 (dimensionless)

$\rho \quad$ Tephra density $\left(\mathrm{kg} / \mathrm{m}^{3}\right)$

$\Phi \quad$ The cumulative normal distribution with mean value $Q_{\text {mean }}$ and standard deviation $Q_{\text {dev }}$ 
Appendix: Some eruptions involving tephra fall and their recorded effects on roofs

\begin{tabular}{|c|c|c|c|c|}
\hline Eruption & Urban Area & Parameters & Consequences & Reference \\
\hline $\begin{array}{l}\text { British Antarctic Territory, } \\
\text { Deception Island, } 1967\end{array}$ & $\begin{array}{l}\text { British and Chilean scien- } \\
\text { tific stations. }\end{array}$ & $\begin{array}{l}\text { - British station survived } 0.08 \\
\text { - Chilean station collapsed wit }\end{array}$ & $\begin{array}{l}\mathrm{n} \text { tephra. } \\
0.50 \mathrm{~m} \text { tephra. }\end{array}$ & Blong (1984) \\
\hline Guatemala, Fuego, 1971 & Yepocapa & $-0.300 \mathrm{~m}$ tephra plus bombs. & $-10-20 \%$ of roofs collapsed & $\begin{array}{l}\text { Blong (1981) } \\
\text { Blong (1984) }\end{array}$ \\
\hline $\begin{array}{l}\text { Guatemala, Santa Maria, } \\
1902\end{array}$ & Suiza and others & $\begin{array}{l}\text { - About } 2.3 \mathrm{~m} \text { tephra on one } \\
\text { roof in Suiza caused col- } \\
\text { lapse; otherwise, level was } \\
\text { approximately } 0.20 \mathrm{~m} \text {. }\end{array}$ & $\begin{array}{l}\text { - About } 2000 \text { deaths likely } \\
\text { from tephra-induced roof } \\
\text { collapse. } \\
\text { - In Suiza, about } 50 \text { deaths } \\
\text { resulted from roof collapse, } \\
\text { but } 950 \text { people survived roof } \\
\text { collapse. }\end{array}$ & Blong (1984) \\
\hline Iceland, Eldfell, 1973 & Heimaey & - $4 \mathrm{~m}$ tephra total. & $\begin{array}{l}\text { - Some roofs collapsed un- } \\
\text { der less than } 1 \mathrm{~m} \text { tephra. } \\
\text { - Many survived the tephra } \\
\text { fall by being cleaned period- } \\
\text { ically. }\end{array}$ & Blong (1984) \\
\hline Indonesia, Agung, 1963 & not specified & - No data given. & $\begin{array}{l}\text { - At least } 163 \text { deaths and } \\
201 \text { injuries from tephra, but } \\
\text { possibly more. }\end{array}$ & $\begin{array}{l}\text { Tiedemann } \\
\text { USGS (2004) }\end{array}$ \\
\hline Indonesia, Tambora, 1815 & Bima & $\begin{array}{l}-0.095 \mathrm{~m} \text { uncompacted } \\
\text { tephra. }\end{array}$ & - Roofs collapsed. & Blong (1981) \\
\hline Italy, Stromboli, 1912 & various & $-0.060-0.080 \mathrm{~m}$ tephra. & - No roof damage. & Blong (1984) \\
\hline Italy, Vesuvius, 79 & Pompeii & $\begin{array}{l}\text { Up to several metres of } \\
\text { tephra. }\end{array}$ & $\begin{array}{l}\text { - Some deaths from frac- } \\
\text { tured skulls, likely from roof } \\
\text { collapse. } \\
\text { - Many people survived } \\
2.8 \mathrm{~m} \text { of tephra fall. } \\
\text { - Roof and wall collapse in } \\
\text { one particular house, but not } \\
\text { necessarily from just tephra }\end{array}$ & $\begin{array}{l}\text { Blong (1984) Luongo et } \\
\text { al. (2003) }\end{array}$ \\
\hline Italy, Vesuvius, 1737 & Ottaviano & $-0.28-0.40 \mathrm{~m}$ tephra likely. & $\begin{array}{l}\text { Many houses were } \\
\text { crushed. }\end{array}$ & Blong (1984) \\
\hline Italy, Vesuvius, 1906 & various & \multicolumn{2}{|c|}{$\begin{array}{l}-0.6-7.0 \mathrm{~m} \text { tephra reported. } \\
-200-300 \text { killed by roof collapse; about the same number } \\
\text { injured. } \\
\text { - Flat roofs in Ottaviano collapsed under } 0.100 \mathrm{~m} \text { of } \\
\text { tephra. } \\
\text {-Buildings in Ottaviano and San Guiseppe collapsed un- } \\
\text { der a tephra depth } 0.7 \mathrm{~m} \text { to several metres. }\end{array}$} & Blong (1984) \\
\hline Italy, Vesuvius, 1944 & Nocera and Pagani. & - No data given. & $\begin{array}{l}-12 \text { deaths at Nocera } \\
\text { and } 9 \text { deaths at Pagani } \\
\text { from tephra-induced roof } \\
\text { collapse. }\end{array}$ & Blong (1984) \\
\hline Japan, Asama, 1783 & not specified & $\begin{array}{l}\text { - Under } 1.1 \mathrm{~m} \text { of uncom- } \\
\text { pacted tephra. }\end{array}$ & $\begin{array}{l}\text { - } 82 \text { out of } 162 \text { houses } \\
\text { crushed. }\end{array}$ & Blong (1984) \\
\hline $\begin{array}{l}\text { Japan, Sakura-jima (Saku- } \\
\text { razima), } 1914\end{array}$ & various & \multicolumn{2}{|c|}{$\begin{array}{l}\text { - Up to } 2,777 \text { buildings possibly destroyed by tephra. } \\
\text { - } 200 \text { buildings in Krokami destroyed by } 1 \mathrm{~m} \text { tephra. } \\
\text { - No houses destroyed in several villages receiving } 0.5 \mathrm{~m} \\
\text { tephra. } \\
\text {-Flat roofs damaged more then steep roofs. }\end{array}$} & $\begin{array}{l}\text { Blong (1981) } \\
\text { Blong (1984) }\end{array}$ \\
\hline Japan, Usu, 1977 & Toyako Spa and Konomi & - 2-8 kPa tephra load. & $\begin{array}{l}\text { - Most buildings were built } \\
\text { to withstand the load im- } \\
\text { posed. } \\
\text { - Roofs of a nursery school } \\
\text { and filtration plant suffered } \\
\text { damage. }\end{array}$ & Blong (1984) \\
\hline Montserrat, 2003 & north part & $\begin{array}{l}\text { - Maximum thickness was } \\
\text { over } 0.15 \mathrm{~m}\end{array}$ & $\begin{array}{l}\text { - Some roofs collapsed; no } \\
\text { injuries reported. }\end{array}$ & MVO (2003) \\
\hline $\begin{array}{l}\text { New Zealand, Tarawera, } \\
1886\end{array}$ & $\begin{array}{l}\text { Te Akriki, Moura, and Te } \\
\text { Wairoa }\end{array}$ & $\begin{array}{l}\text { - No data given, but refer- } \\
\text { ence provided. }\end{array}$ & $\begin{array}{l}\text { Most of the } 150 \text { deaths } \\
\text { were from tephra-induced } \\
\text { roof collapse. }\end{array}$ & Blong (1984) \\
\hline $\begin{array}{l}\text { Nicaragua, Cerro Negro, } \\
1992\end{array}$ & León & $\begin{array}{l}\text { - Trace amounts to } 0.04 \mathrm{~m} \\
\text { tephra. }\end{array}$ & $\begin{array}{l}\text { - At least } 2 \text { deaths and } 146 \\
\text { injured from building col- } \\
\text { lapse. }\end{array}$ & Connor et al. (2001) \\
\hline Philippines, Pinatubo, 1991 & not specified & $\begin{array}{l}\text { - More than } 0.5 \mathrm{~m} \text { of tephra } \\
\text { near the vent. }\end{array}$ & $\begin{array}{l}\text { - Most immediate casual- } \\
\text { ties were on } 15 \text { June from } \\
\text { roof collapse under tephra } \\
\text { which was wet from Ty- } \\
\text { phoon Yunya. }\end{array}$ & $\begin{array}{l}\text { PVOT (1991) } \\
\text { Wolfe (1992) }\end{array}$ \\
\hline Philippines, Pinatubo, 1991 & Castillejos & \multicolumn{2}{|c|}{$\begin{array}{l}\text { - A design load of } 2.0 \mathrm{kPa} \text { would have prevented roof col- } \\
\text { lapse. } \\
\text { - Some roofs survived } 0.15 \mathrm{~m} \text { tephra. }\end{array}$} & Spence et al. (1996) \\
\hline Philippines, Taal, 1754 & not specified & $-1.1 \mathrm{~m}$ uncompacted tephra. & - Damage to church roof. & Blong (1984) \\
\hline PNG, Long Island & various & $\begin{array}{l}\text { - "Fine dusting" to over } 2 \mathrm{~m} \\
\text { tephra. }\end{array}$ & $\begin{array}{l}\text { - Building and roof collapses } \\
\text { occurred. Some residents } \\
\text { took mitigating steps. }\end{array}$ & Blong (1982) \\
\hline $\begin{array}{l}\text { PNG, Tavurvur and Vulcan, } \\
1937\end{array}$ & Rabaul & -About $0.10 \mathrm{~m}$ tephra. & - No roof damage. & Blong (1984) \\
\hline $\begin{array}{l}\text { PNG, Tavurvur and Vulcan, } \\
1994\end{array}$ & Rabaul & \multicolumn{2}{|c|}{$\begin{array}{l}-0.5-1.0 \mathrm{~m} \text { wet tephra collapsed most roofs. } \\
-0.1-0.3 \mathrm{~m} \text { tephra caused little damage. } \\
- \text { The two tephras were different, so load is a more ap- } \\
\text { propriate measure. } 2-15 \mathrm{kPa} \text { were experienced. Damage } \\
\text { ranged from light damage to collapse. } \\
\text {-All collapses experienced }>7.5 \mathrm{kPa} \text { tephra load. } \\
\text {-Some severe damage was experienced for } 2-5 \mathrm{kPa} \text { tephra } \\
\text { load. } \\
\text {-Mudfills from wet tephra flowed into buildings and } \\
\text { caused damage. }\end{array}$} & $\begin{array}{l}\text { Blong (1994) } \\
\text { Blong (2003) }\end{array}$ \\
\hline PNG, Ulawan, 1967 & not specified & $\begin{array}{l}-0.010-0.012 \mathrm{~m} \text { uncom- } \\
\text { pacted tephra. }\end{array}$ & - Minor damage. & Blong (1984) \\
\hline St. Vincent, Soufrière, 1812 & not specified & $-0.150-0.250 \mathrm{~m}$ tephra. & - Roofs collapsed. & Blong (1984) \\
\hline St. Vincent, Soufrière, 1902 & not specified & \multicolumn{2}{|c|}{$\begin{array}{l}-0.075-0.125 \mathrm{~m} \text { tephra caused roofs to collapse. } \\
-0.460 \text { tephra caused houses to collapse. }\end{array}$} & Blong (1984) \\
\hline $\begin{array}{l}\text { USA, Alaska, Katmai- } \\
\text { Novarupta, } 1912\end{array}$ & Kodiak & $-0.3-0.5 \mathrm{~m}$ tephra. & $\begin{array}{l}\text { - Fewer than three deaths to- } \\
\text { tal from the eruption and its } \\
\text { aftermath. }\end{array}$ & Blong (1984) \\
\hline
\end{tabular}


Acknowledgements. The authors thank A. Neri, D. Purser, J. Gaspar, J.-C. Komorowski, J. Martí, and their teams for field assistance, data, and ideas which made this work possible. A. Brown, E. Calogero, O. Cornella, W. Fawcett, A. Gomes, D. Haigh, T. Hincks, J. Hrivnak, C. Magill, D. Oramas, J. Purser, and K. Scott contributed to the field surveys. The European Union provided the funding which made this research possible through the project Explosive Eruption Risk and Decision Support for EU Populations Threatened by Volcanoes (EXPLORIS) EVR1-2001-00047. Two referees provided helpful comments and the EGU Editorial Office provided support.

Edited by: J. Martí

Reviewed by: A. Felpeto and another referee

\section{References}

Barberi, F., Macedonio, G., Pareschi, M. T., and Santacroce, R.: Mapping the Tephra Fallout Risk: An example from Vesuvius, Italy, Nature, 44, 142-144, 1990.

Baxter, P. J. and Gresham, A.: Deaths and injuries in the eruption of Galeras Volcano, Colombia, 14 January 1993, J. Volcanol., 77, 325-338, 1997.

Baxter, P. J., Kapila, M., and Mfonfu, D.: Lake Nyos disaster, Cameroon, 1986: The medical effects of large scale emission of carbon dioxide, Br. Med. J., 298, 1437-1441, 1989.

Bernstein, R. S., Baxter, P. J., Falk, H., Ing, R., Foster, L., and Frost, F.: Immediate public health concerns and actions in volcanic eruptions: lessons from the Mount St. Helens eruptions, 18 May-18 October, 1980. Am. J. Pub. He., 76, 25-37, 1986.

Blong, R. J.: Some Effects of Tephra Falls on Buildings, in: Tephra Studies: Proc. NATO Advanced Study Institute Tephra Studies as a Tool in Quaternary Research, edited by: Self, S. and Sparks, R. S. J., held in Laugarvatn and Reykjavík, Iceland, 18-29 June 1980, D. Reidel Publishing Company, Dordrecht, Netherlands, 405-420, 1981.

Blong, R. J.: The Time of Darkness: Local Legends and Volcanic Reality in Papua New Guinea, University of Washington Press, London, UK, 1982.

Blong, R. J.: Volcanic Hazards: A Sourcebook on the Effects of Eruptions, Academic Press, London, UK, 1984.

Blong, R. J.: The Rabaul Eruption, Australian Geographer, 25, 186190, 1994.

Blong, R. J.: Volcanic Hazards Risk Assessment, in: Monitoring and Mitigation of Volcano Hazards, edited by: Scarpa, R. and Tilling, R. I., Springer-Verlag, Berlin, Heidelberg, 676-698, 1996.

Blong, R. J.: Volcanic Hazards and Risk Management, Chapter 7 in Part VIII: Eruption Response and Mitigation of Sigurdsson, H. (editor-in-chief), Encyclopedia of Volcanoes, Academic Press, UK, 2000.

Blong, R. J.: Building Damage in Rabaul, Papua New Guinea, 1994, B. Volcanol., 65, 43-54, 2003.

Blong, R. J. and McKee, C.: The Rabaul eruption 1994: Destruction of a town, Natural Hazard Research Centre, Macquarie University, Sydney, Australia, 1995.

Bonadonna, C. and Sparks, R. S. J.: Assessment of Tephra Fallout Hazard and Risk for Montserrat, MVO Special Report 9, Montserrat Volcano Observatory, Government of Montserrat, April 2002.
Bruce, V.: No Apparent Danger: The True Story of Volcanic Disaster at Galeras and Nevado Del Ruiz, HarperCollins, New York, USA, 2001.

BS 6399-3: Loading for Buildings. Code of Practice for Imposed Roof Loads, British Standards Institution, London, UK, 1988.

Clay, E.: An evaluation of HMG's response to the Montserrat Volcanic Emergency, DFID (Department for International Development) Evaluation Report EV635, London, UK, 1999.

Coburn, A. W., Spence, R. J. S., and Pomonis, A.: Factors determining human casualty levels in earthquakes: mortality prediction in building collapse, Proc. 10th World Conference on Earthquake Engineering, Madrid, July 1992, A.A. Balkema, Rotterdam, 5989-5994, 1992.

Coburn, A. W. and Spence, R. J. S.: Earthquake Protection, 2nd ed. John Wiley \& Sons, Chichester, UK, 2002.

Colquhoun, J.: Comment (on Ronan, 1997), Fluoride, 31, 223-224, 1998.

Connor, C. B., Hill, B. E., Winfrey, B., Franklin, N. M., and La Femina, P. C.: Estimation of Volcanic Hazards from Tephra Fallout, Nat. Hazards Rev., 2, 1, 33-42, 2001.

Coppa, U., Petrazzuoli, S. M., and Zuccaro, G.: An Assessment of the Resistance of Building Slabs Using Vertical Vibrational Analysis, Presentation at The 8th World Multi-conference on Systemics, Cybernetics and Informatics, 18-21 July 2004 Orlando, Florida, USA, 2004.

Department of Civil Protection: National Emergency Plan for the Vesuvius Area, Prefettura di Napoli, Naples, Italy, 2001.

Etkin, D.: Risk Transference and Related Trends: Driving Forces Towards More Mega-Disasters, Env. Haz., 1, 69-75, 1999.

Forbes, L., Jarvis, D., Potts, J., and Baxter, P. J.: Volcanic Ash and Respiratory Symptoms in Children on the Island of Montserrat, British West Indies. Occup. Environ. Med., 60, 207-211, 2003.

Fordham, M.: Participatory Planning for Flood Mitigation: Models and Approaches, The Australian Journal of Emergency Management, 13, 4, 27-34, 1999.

Grünthal, G. (ed.): European Macroseismic Scale: EMS-98, Centre Europèen de Géodynamique et de Séismologie, Conseil de l'Europe, Luxembourg, 1998.

Hansell, A. L.: Respiratory Effects of Volcanic Emissions, Occup. Environ. Med., 60, 529-530, 2003.

Hickling, J., Clements, M., Weinstein, P., and Woodward, A.: Acute Health Effects of the Mount Ruapehu (New Zealand) Volcanic Eruption of June 1996, Int. J. Env. Hlth. Research, 9, 97-107, 1999.

Ivanovic, S. S., Trifunac, M. D., and Teodorovska, M. I.: Ambient Vibration Tests of Structures - A Review, B. Indian Society of Earthquake Technicians, 37(4), 165-197, 2000.

James, G. H., Carne, T. G., and Lauffer, J. P.: The Natural Excitation Technique for Modal Parameter Extraction from Operating Wind Turbines, Report SAND92-1666, UC-261, Sandia National Laboratories, USA, 1993.

Kelman, I.: The Autumn 2000 Floods in England and Flood Management, Weather, 56, 346-348, 353-360, 2001.

Kircher, C. A. and Hamburger, R. O. (eds.): Earthquake Spectra theme issue on Seismic Design Provisions and Guidelines, 16, 1, 2000.

Luongo, G., Perrotta, A., and Scarpati, C.: Impact of the AD 79 explosive eruption on Pompeii, I. Relations amongst the depositional mechanisms of the pyroclastic products, the framework of the buildings and the associated destructive events, J. Volcanol., 126, 201-223, 2003. 
MVO: Summary of the 12-15 July 2003 dome collapse and explosive activity at the Soufrière Hills Volcano, Montserrat. MVO (Montserrat Volcano Observatory), Montserrat, 2003.

Newhall, C. G. and Punongbayan, R. S. (eds.): Fire and Mud: Eruptions and Lahars of Mount Pinatubo, Philippines. University of Washington Press, London, UK, 1996.

Pattullo, P.: Fire from the Mountain: The tragedy of Montserrat and the betrayal of its people. Constable and Robinson, London, UK, 2000.

Pomonis, A., Spence, R., and Baxter, P. J.: Risk Assessment of Residential Buildings for an Eruption of Furnas Volcano, São Miguel, the Azores, J. Volcanol., 92, 107-131, 1999.

Porter, N. and Williams, A.-M.: The Effects of Volcanic Ash Loading on Corrugated Sheet Steel Roofs, University of Bristol, Civil Engineering, 3rd Year Research Project for the Degree of Master of Engineering, May 2000.

PVOT (Pinatubo Volcano Observatory Team): Lessons from a Major Eruption: Mt. Pinatubo, Philippines, EOS, 72, 545, 552-555, 3 December 1991.

Pyle, D. M.: The Thickness, Volume and Grainsize of Tephra Fall Deposits, B. Volcanol., 51, 1-15, 1989.

Ronan, K. R.: The Effects of a Series of Volcanic Eruptions on Emotional and Behavioural Functioning in Children With Asthma. NZ Med. J., 25 April 1997.

Samaranayake, D., Hope, V., and Dirks, K.: Health Impacts in Auckland of the Mt Ruapehu Volcanic Eruption of 1996, Presentation at the International Conference on Storms, 5-9 July 2004, Brisbane, Australia, 2004.

Schreiver, W. R. and Hansen, A. T.: Snow Loads and Strength of Small Roofs in Canada, Forest Prod., 14, 3, 129-136, 1964.

Sigvaldason, G. E.: Reply to editorial, J. Volcanol., 4, 3-4, I-III, 1978.
Simkin, T., Siebert, L., and Blong, R.: Volcano Fatalities-Lessons from the Historical Record, Science, 291, 255, 2001.

Spence, R. J. S., Pomonis, A., Baxter, P. J., Coburn, A. W., White, M., Dayrit, M., and Field Epidemiology Training Program Team: Building Damage Caused by the Mount Pinatubo Eruption of 15 June 1991, in: Fire and Mud: Eruptions and Lahars of Mount Pinatubo, Philippines, edited by: Newhall, C. G. and Punongbayan, R. S., University of Washington Press, London, UK, 1055-1061, 1996.

Spence, R. J. S., Zuccaro, G., Petrazzuoli, S., and Baxter, P. J.: Resistance of Buildings to Pyroclastic Flows: Analytical and Experimental Studies and Their Application to Vesuvius, Nat. Hazards Rev., 5, 1, 48-59, 2004.

Tazieff, H.: La Soufrière: volcanology and forecasting, Nature, 269, 96-97, 1977.

Tiedemann, H.: Earthquakes and Volcanic Eruptions: A Handbook on Risk Assessment, Swiss Reinsurance Company, Zurich, Switzerland, 1992.

Tobin, G. A. and Whiteford, L. M.: Community Resilience and Volcano Hazard: The Eruption of Tungurahua and Evacuation of the Faldas in Ecuador, Disasters, 26, 28-48, 2002.

USGS (United States Geological Survey): Notable Volcanic Disasters, http://volcanoes.usgs.gov/Hazards/Effects/Fatalities.html on 28 October 2004.

Wolfe, E. W.: The 1991 Eruptions of Mount Pinatubo, Philippines, Earthquakes \& Volcanoes, 23, 1, 5-37, 1992.

Zuccaro, G.: Structural vulnerability to possible flows consequent to the eruption of the volcano Vesuvius, Final Report for EC Project ENV4-CT98-0699, Laboratorio di Urbanistica e Pianificazione Territoriale, University of Naples, 2000. 